Article

\title{
Synthesis and Evaluation of New Benzodioxole-Based Thiosemicarbazone Derivatives as Potential Antitumor Agents
}

\author{
Mehlika Dilek Altıntop ${ }^{1, *}$, Halide Edip Temel ${ }^{2}$, Belgin Sever ${ }^{1}$, Gülsşen Akalın Çiftçi ${ }^{2}$ \\ and Zafer Asım Kaplancıklı 1 \\ 1 Department of Pharmaceutical Chemistry, Faculty of Pharmacy, Anadolu University, \\ 26470 Eskişehir, Turkey; belginsever@anadolu.edu.tr (B.S.); zakaplan@anadolu.edu.tr (Z.A.K.) \\ 2 Department of Biochemistry, Faculty of Pharmacy, Anadolu University, 26470 Eskişehir, Turkey; \\ heincedal@anadolu.edu.tr (H.E.T.); gakalin@anadolu.edu.tr (G.A.Ç.) \\ * Correspondence: mdaltintop@anadolu.edu.tr; Tel.: +90-222-335-0580 (ext. 3772); Fax: +90-222-335-0750 \\ Academic Editor: Derek J. McPhee \\ Received: 22 July 2016; Accepted: 18 November 2016; Published: 22 November 2016
}

\begin{abstract}
New benzodioxole-based thiosemicarbazone derivatives were synthesized and evaluated for their cytotoxic effects on A549 human lung adenocarcinoma, C6 rat glioma and NIH/3T3 mouse embryonic fibroblast cells. In order to examine the correlation between anticancer activity and cholinesterases, the compounds were evaluated for their inhibitory effects on AChE and $\mathrm{BuChE}$. The most effective anticancer agents were investigated for their effects on DNA synthesis, apoptosis and mitochondrial membrane potential. 4-(1,3-Benzodioxol-5-yl)-1-([1,1'-biphenyl]-4ylmethylene)thiosemicarbazide (5) was identified as the most promising anticancer agent against C6 and A549 cell lines due to its inhibitory effects on C6 and A549 cells and low toxicity to NIH/3T3 cells. Compound 5 increased early and late apoptosis in A549 and C 6 cells. Compound 5 also caused disturbance on mitochondrial membrane potential and showed DNA synthesis inhibitory activity in A549 and C 6 cells. Compound 5 was investigated for SIRT1 inhibitory activity to provide mechanistic insight and for that purpose docking studies were also performed for this compound on SIRT1. On the other hand, compound $\mathbf{5}$ did not show any inhibitory activity against AChE and BuChE. This outcome pointed out that there is no relationship between anticancer activity of compound 5 and cholinesterases.
\end{abstract}

Keywords: thiosemicarbazone; benzodioxole; cancer; apoptosis; mitochondrial membrane potential; SIRT1; docking studies

\section{Introduction}

Cancer is an abnormal cell division caused by some alteration in the expression of plentiful genes in the nucleus or in the mitochondria of cells. These alterations lead to a disorder in the balance between cell reproduction and cell death. Indeed, cancer is not a single disease, but rather it is a group of more than a hundred distinct diseases affecting different organs and systems of the body. Up to now, many chemotherapeutic drugs have been developed as anticancer agents, but most of them are insufficient for cancer treatment because of their lack of specificity towards cancer cells and correspondingly their high risk of toxicity to normal cells. Consequently, pharmaceutical research has focused on the discovery of more selective and less toxic anticancer agents [1-6].

Acetylcholinesterase (AChE) and butyrylcholinesterase (BuChE) are abnormally expressed in various pathological conditions, such as tumorigenesis. In recent years, AChE has attracted a great deal of interest as a potential therapeutic target for the treatment of cancer due to the involvement of this enzyme in apoptosis and cell adhesion, differentiation, and proliferation [7-9]. 
The mammalian sirtuins are a family of NAD ${ }^{+}$-dependent enzymes that have been connected to a great variety of biological activities encompassing cellular stress resistance, genomic stability, tumorigenesis and energy metabolism. Among them, sirtuin-1 (SIRT1) which belongs to the class III histone deacetylases (HDACs), is associated with a wide range of human diseases and is an outstanding potential therapeutic target. Overexpression of SIRT1 has been reported to increase growth and survival rates of some cancer cell lines and inhibit apoptosis [10-13]. However, the role of sirtuins as tumor suppressor or tumor promoter in some types of cancer is more diverse and complex than previously anticipated due to cellular context or targets in specific signaling pathways [14].

Thiosemicarbazones have been the subject of considerable research due to their wide range of biological activities such as antitumor, antibacterial, antifungal and antiviral effects. Since the 1950s, their anticancer activity has been continually investigated and some of them were explored as antileukemic agents. Thiosemicarbazones have iron coordination capacity and the complexation with most of the transition metal ions has increased their use as potential antitumor agents. The antitumor activity of thiosemicarbazones has mainly been associated with their inhibition capacity of ribonucleotide reductase, which is the rate limiting enzyme in the synthesis and repair of DNA. The ability of thiosemicarbazones to chelate metal ions has been defined as a major mechanism in the inhibition of ribonucleotide reductase. For this purpose, 3-aminopyridine-2-carboxaldehyde thiosemicarbazone (3-AP or Triapine ${ }^{\circledR}$ ), a promising potent molecule, was studied in several clinical phase I and II trials where it was found to be ineffective against a variety of solid tumors but very promising against hematologic malignancies such as leukemia. Triapine ${ }^{\circledR}$ was 1000 times more potent than the clinically used ribonucleotide reductase inhibitor hydroxyurea in both enzyme and cell assays. Recent studies have also showed that thiosemicarbazones inhibit topoisomerase-II $\alpha$ enzyme, which is highly expressed in many cancer cells acting by stabilization of the cleavable products formed by topoisomerase-II and DNA through a thiol alkylation. In the recent times, thiosemicarbazones were reported to inhibit ATP binding cassette $(\mathrm{ABC})$ transporters, which are involved in the development of multidrug resistance [15-23]. On the other hand, 1,3-benzodioxole is found in a variety of anticancer agents such as podophyllotoxin, steganacin, and combretastatin A-2 showing good bioavailability and low cytotoxicity [24].

On the basis of aforementioned findings, in the present investigation we report the synthesis and evaluation of a new series of benzodioxole-based thiosemicarbazone derivatives as anticancer agents against A549 human lung adenocarcinoma, C6 rat glioma and NIH/3T3 mouse embryonic fibroblast (healthy) cell lines. The synthesized compounds were evaluated for their inhibitory effects on AChE and $\mathrm{BuChE}$ to examine the correlation between anticancer activity and cholinesterases. Furthermore, the most effective anticancer agents were also evaluated for their effects on DNA synthesis, apoptosis and mitochondrial membrane potential. The SIRT1 inhibitory action of compound 5, the most promising anticancer agent, was investigated to provide mechanistic insight and suggest a therapeutic role for this compound. Docking studies were also performed for compound 5 on SIRT1 (PDB Id: 4IG9).

\section{Results and Discussion}

\subsection{Chemistry}

The synthesis of thiosemicarbazone derivatives 1-10 was carried out according to the steps depicted in Scheme 1. In the initial step, 4-(1,3-benzodioxole-5-yl)thiosemicarbazide (A) was synthesized via the reaction of 1,3-benzodioxole-5-yl isothiocyanate with hydrazine hydrate. The reaction of 4-(1,3-benzodioxole-5-yl)thiosemicarbazide (A) with aromatic aldehydes afforded new thiosemicarbazone derivatives $\mathbf{1 - 1 0}$. The IR, ${ }^{1} \mathrm{H}-\mathrm{NMR},{ }^{13} \mathrm{C}-\mathrm{NMR}$, mass spectral data and elemental analyses were in agreement with the proposed structures of the compounds 1-10 (see Supplementary Figures for further details). 


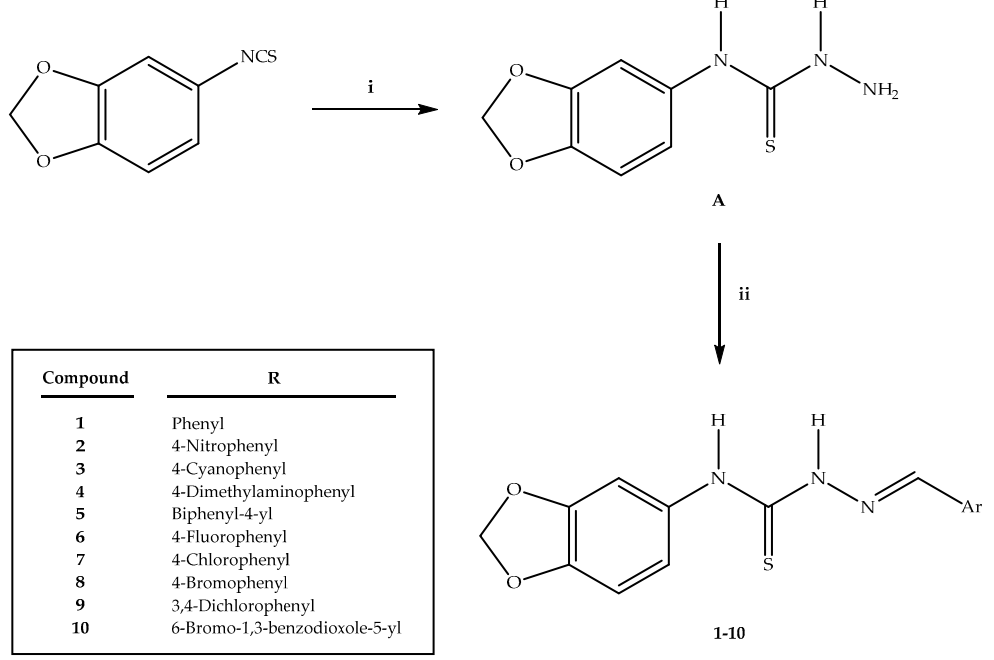

Scheme 1. The synthetic route for the preparation of the thiosemicarbazone derivatives 1-10. Reagents and conditions: (i) $\mathrm{NH}_{2} \mathrm{NH}_{2} \cdot \mathrm{H}_{2} \mathrm{O}$, ethanol, rt, 4 h; (ii) Ar-CHO, ethanol, reflux, $8 \mathrm{~h}$.

\subsection{Biochemistry}

\subsubsection{Cytotoxicity}

MTT assays were carried out to determine the cytotoxic effects of the compounds on A549 human lung adenocarcinoma and C6 rat glioma cell lines. According to assay results, the tested compounds, except compound 3, showed more potent inhibitory effects on C6 cells than A549 cells. The most effective cytotoxic agent against A549 cancer cell line was found as compound 5 $\left(\mathrm{IC}_{50}=10.67 \pm 1.53 \mu \mathrm{M}\right)$ followed by compounds 2, 3, 10 and $\mathbf{9}\left(\mathrm{IC}_{50}\right.$ values were $24.0 \pm 3.46$, $28.0 \pm 1.0,29.67 \pm 5.51$ and $51.5 \pm 4.95 \mu \mathrm{M}$, respectively). Furthermore, the most effective cytotoxic agent against the $\mathrm{C} 6$ glioma cell line was found as compound $5\left(\mathrm{IC}_{50}=4.33 \pm 1.04 \mu \mathrm{M}\right)$, followed by compounds 10, 2,9 and 3 ( $\mathrm{IC}_{50}$ values were $12.33 \pm 4.93,23.33 \pm 2.08,25.33 \pm 1.53$, and $49.33 \pm 1.15 \mu \mathrm{M}$, respectively, Table 1$)$.

Table 1. IC 50 values of the compounds against A549, C6 and NIH/3T3 cells for $24 \mathrm{~h}$.

\begin{tabular}{cccc}
\hline \multirow{2}{*}{ Compound } & \multicolumn{3}{c}{ IC $_{\mathbf{5 0}}(\boldsymbol{\mu M})$} \\
\cline { 2 - 4 } & A549 Cell Line & C6 Cell Line & NIH/3T3 Cell Line \\
\hline $\mathbf{1}$ & $>167.0$ & $>167.0$ & $>167.0$ \\
$\mathbf{2}$ & $24.0 \pm 3.46$ & $23.33 \pm 2.08$ & $>145.2$ \\
$\mathbf{3}$ & $28.0 \pm 1.0$ & $49.33 \pm 1.15$ & $>154.1$ \\
$\mathbf{4}$ & $>146.0$ & $>146.0$ & $>146.0$ \\
$\mathbf{5}$ & $10.67 \pm 1.53$ & $4.33 \pm 1.04$ & $21.33 \pm 5.77$ \\
$\mathbf{6}$ & $>157.6$ & $>157.6$ & $2.87 \pm 0.05$ \\
$\mathbf{7}$ & $>149.7$ & $>149.7$ & $9.50 \pm 2.50$ \\
$\mathbf{8}$ & $>132.2$ & $>132.2$ & $9.16 \pm 2.47$ \\
$\mathbf{9}$ & $51.5 \pm 4.95$ & $25.33 \pm 1.53$ & $>135.8$ \\
$\mathbf{1 0}$ & $29.67 \pm 5.51$ & $12.33 \pm 4.93$ & $38.33 \pm 2.08$ \\
Cisplatin & $3.0 \pm 0.88$ & $6.83 \pm 0.28$ & $\mathrm{ND}$ \\
\hline
\end{tabular}

ND: Not determined.

On the other hand, compounds 1, 4, 6, 7 and 8 showed no significant cytotoxicity at the concentrations used in both cancer cell lines. The cytotoxicity of compounds 1, 2, 3, 4, 5, 9 and 10 against $\mathrm{NIH} / 3 \mathrm{~T} 3$ cells was lower, whereas the cytotoxicity of compounds 6, 7 and 8 was higher compared to the toxicity on cancer cells (Table 1). These results indicated that the substituents on the benzene ring had 
considerable influence on the cytotoxic effects of the compounds. Considering the anticancer effects of compound 5, it can be concluded that biphenyl substituent increased the anticancer activity against A549 human lung adenocarcinoma and C6 rat glioma cell lines. The increased anticancer activity can be attributed to the increased lipophilicity of the compound due to the presence of biphenyl group.

\subsubsection{Evaluation of DNA Synthesis Inhibition}

The immunostaining procedure was carried out with specific anti-BrdU antibodies in the S-phase of the cell cycle [25]. DNA synthesis inhibitory effects of all compounds were evaluated for $24 \mathrm{~h}$. A549 and C6 cell lines were incubated with three different concentrations of the compounds that were determined according to their $\mathrm{IC}_{50}$ values. Cisplatin was used as a positive control. The tested compounds showed DNA synthesis inhibitory activity in a dose-dependent manner.

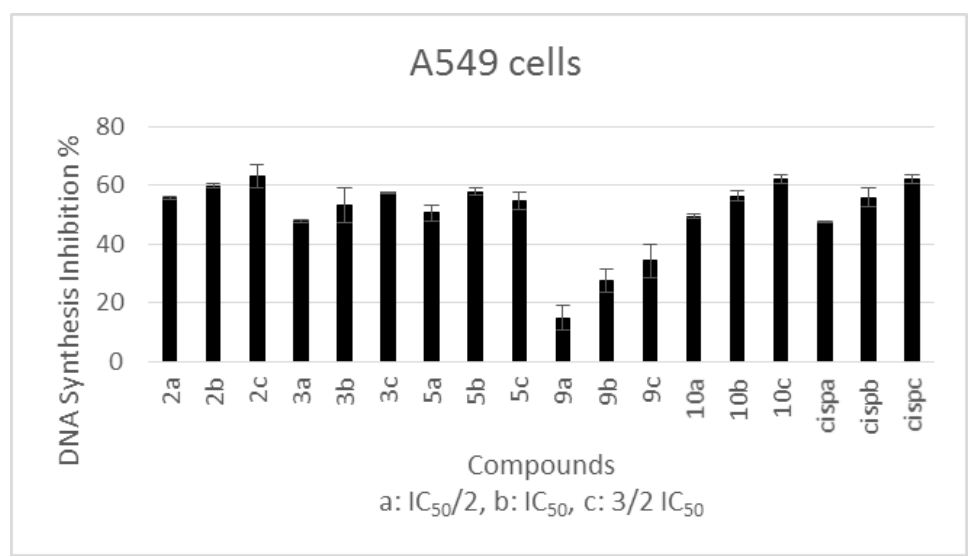

(A)

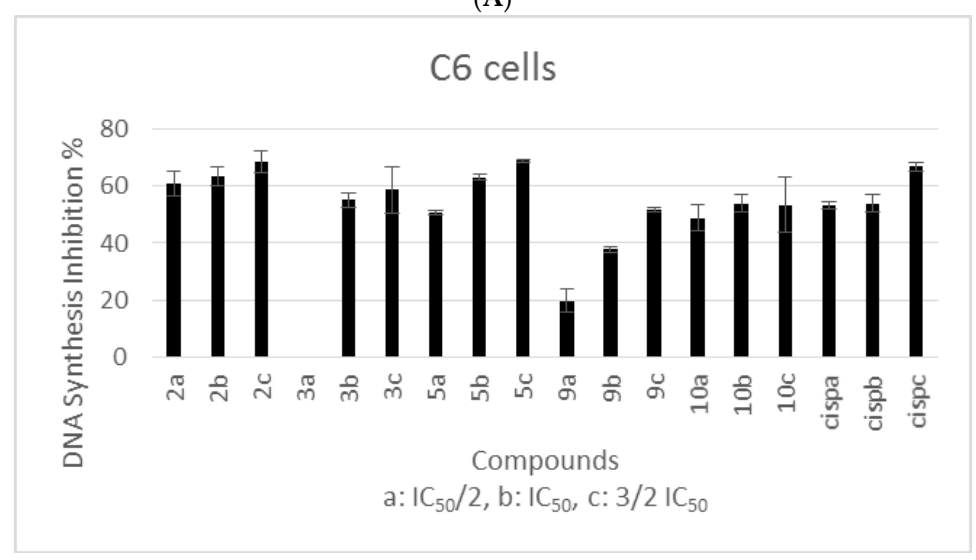

(B)

Figure 1. DNA Synthesis inhibitory effects of compounds 2, 3, 5, 9, 10 and cisplatin on A549 (A) and C6 (B) cells. Mean percent absorbance of untreated control cells were assumed $0 \%$. Three different concentrations ( $\mathrm{a}: \mathrm{IC}_{50} / 2$, b: $\mathrm{IC}_{50}, \mathrm{c}: 3 / 2 \mathrm{IC}_{50}$ ) of test compounds and cisplatin were given. Data points represent means for two independent experiments $\pm \mathrm{SD}$ of four independent wells. $p<0.05$.

The most cytotoxic compounds (compounds 2, 3, 5, 9 and 10) against A549 and C6 cells were chosen for DNA synthesis inhibition assay. DNA synthesis inhibitory activity of the compounds on A549 and C6 cell lines is presented in Figure 1. These results showed that compounds tested in this assay caused DNA synthesis inhibition. Among these compounds, the most potent inhibitors of DNA synthesis against A549 and C6 cell lines were found as compounds 2, 5 and 10. DNA synthesis inhibition caused by the concentration of $\mathrm{IC}_{50}$ for each compound tested in $\mathrm{A} 549$ cell line revealed the following potency order: Compound $\mathbf{2}>$ Compound $\mathbf{5}>$ Compound $\mathbf{1 0}>$ Compound $\mathbf{3}>$ Compound 9. A significant inhibition of A549 proliferation by cisplatin (positive control) at its $\mathrm{IC}_{50}$ 
value $(3.0 \pm 0.88 \mu \mathrm{M})$ was observed (55.73\%). DNA synthesis inhibition percents of compounds 2, 5, 10, 3 and 9 were 59.85\%, 57.79\%, 56.38\%, 53.24\%, 27.3\%, respectively (Figure 1A). On the other hand, DNA synthesis inhibition caused by the concentration of $\mathrm{IC}_{50}$ for each compound tested in $\mathrm{C} 6$ cell line revealed the following potency order: Compound $\mathbf{2}>$ Compound $\mathbf{5}>$ Compound $\mathbf{3}>$ Compound $\mathbf{1 0}>$ Compound 9. DNA synthesis inhibition percents of compounds 2, 5, 3, 10 and 9 were 63.34\%, 62.98\%, $54.99 \%, 53.96 \%$ and $37.71 \%$, respectively, while the inhibition percent of cisplatin was $53.95 \%$ at its $\mathrm{IC}_{50}$ value $(6.83 \pm 0.28 \mu \mathrm{M})$ (Figure 1B). Consequently, the compounds showed similar antiproliferative activities against both cell lines. Compounds 2, $\mathbf{5}$ and $\mathbf{1 0}$ were the most cytotoxic agents and exhibited more inhibitory effects on DNA synthesis. In this regard, we investigated possible mechanism of anticancer activity of these compounds.

\subsubsection{Evaluation of Flow Cytometric Analyses}

\section{Apoptosis}

After $24 \mathrm{~h}$ incubation period, the apoptotic effects of compounds 2, $\mathbf{5}$ and $\mathbf{1 0}$ which were analyzed for A549 human lung adenocarcinoma and C6 rat glioma cells based on Annexin V-PI binding capacities in flow cytometry are depicted in Figures 2 and 3, respectively.
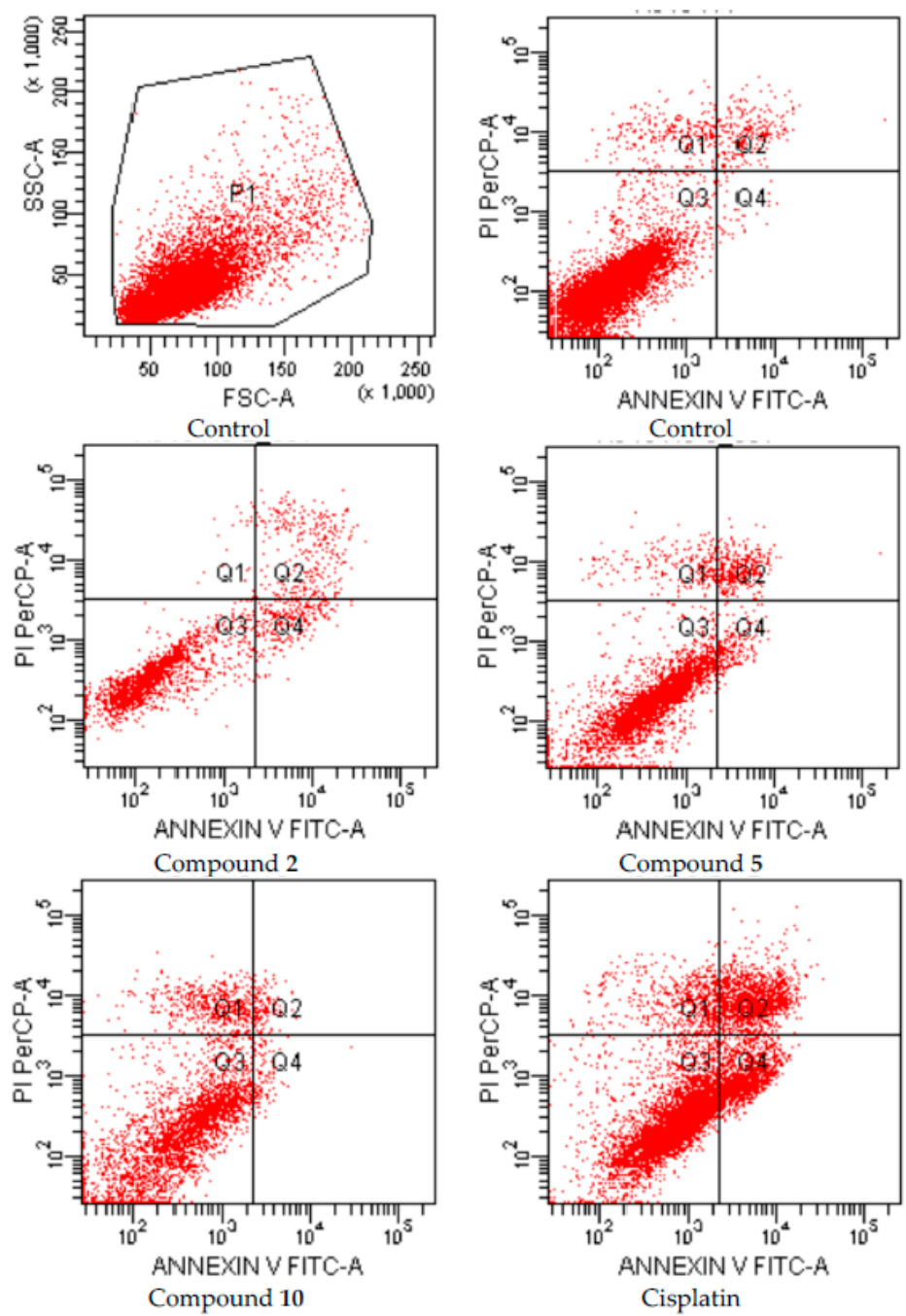

Figure 2. Flow cytometric analysis of $\mathrm{A} 549$ cells treated with $\mathrm{IC}_{50}$ values of compounds 2, 5, 10 and cisplatin. A549 cells were cultured for $24 \mathrm{~h}$ in medium with $\mathrm{IC}_{50}$ values of the compounds. At least 10,000 cells were analyzed per sample, and quadrant analysis was performed. 

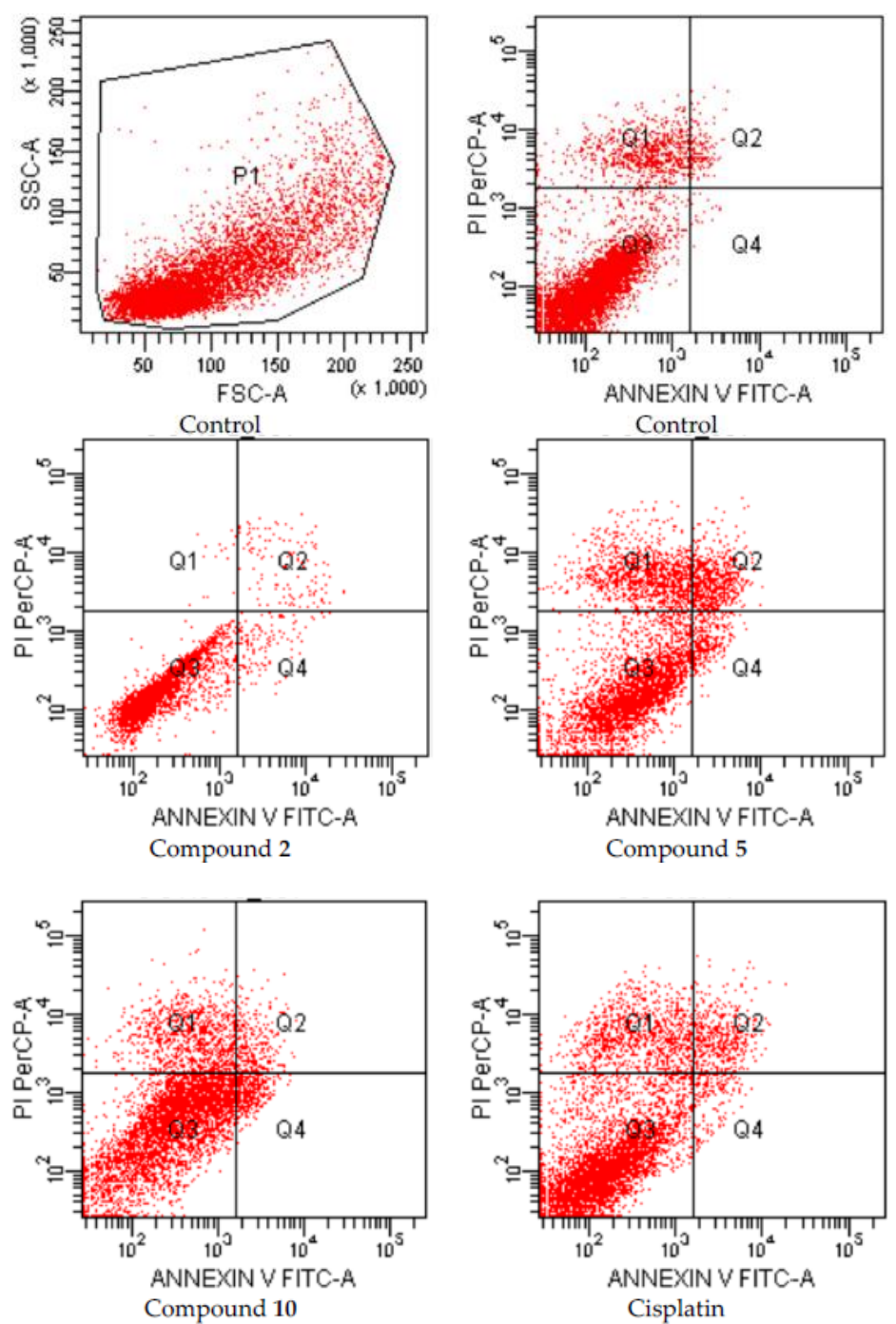

Figure 3. Flow cytometric analysis of $\mathrm{C} 6$ cells treated with $\mathrm{IC}_{50}$ values of compounds 2, 5, 10 and cisplatin. $\mathrm{C} 6$ cells were cultured for $24 \mathrm{~h}$ in medium with $\mathrm{IC}_{50}$ values of the compounds. At least 10,000 cells were analyzed per sample, and quadrant analysis was performed.

Following flow cytometric analyses, early and late apoptotic effects of compounds $\mathbf{2 , 5}$, and $\mathbf{1 0}$ (for $\mathrm{IC}_{50}$ doses) were determined as percentage of 23.7, 12.11 and 6.2 , respectively, while early and late apoptotic effects of control cells were determined as percentage of 3.1 on A549 cell line (Figure 2, Table 2).

Table 2. The percents of typical quadrant analysis of annexin V-FITC/propidium iodide flow cytometry of A549 and C6 cells treated with the compounds.

\begin{tabular}{ccccc}
\hline \multirow{2}{*}{ Groups } & \multicolumn{2}{c}{ Early and Late Apoptotic Cells \% } & \multicolumn{2}{c}{ Viability \% } \\
\cline { 2 - 5 } & C6 Cells & A549 Cells & C6 Cells & A549 Cells \\
\hline Control (untreated) & 4.5 & 3.1 & 83.9 & 94.3 \\
Compound 2 treated cells & 5.4 & 23.7 & 94.5 & 75.2 \\
Compound 5 treated cells & 25.0 & 12.11 & 60.2 & 81.8 \\
Compound 10 treated cells & 15.8 & 6.2 & 69.6 & 81.2 \\
Cisplatin treated cells & 16.3 & 32.4 & 69.0 & 60.5 \\
\hline
\end{tabular}

C6 and A549 cells were cultured for $24 \mathrm{~h}$ in medium with $\mathrm{IC}_{50}$ values of the compounds. At least 10,000 cells were analyzed per sample, and quadrant analysis was performed. 
On the other hand, early and late apoptotic effects of compounds 2, 5, and 10 (for $\mathrm{IC}_{50}$ doses) were determined as percentage of 5.4, 25.0, and 15.8, respectively, while early and late apoptotic effects of control cells were determined as percentage of 4.5 on C6 cell line (Figure 3, Table 2). According to these findings, compound 5 was the most effective apoptotic compound $(25.0 \%)$ on C6 cells compared to cisplatin $(16.3 \%)$. On the other hand, the compounds were not effective as cisplatin (32.4\%) on A549 cells.

Mitochondrial Membrane Potential (JC-1)

During apoptosis, several key events occur in mitochondria including the release of cytochrome c, changes in electron transport, and loss of mitochondrial transmembrane potential $(\Delta \Psi \mathrm{m})$. For this reason, $\Delta \Psi \mathrm{m}$ is an important parameter of mitochondrial function in apoptosis [26]. In order to investigate effects of compounds 2, 5 and $\mathbf{1 0}$ on mitochondrial membrane potential of A549 and C6 cells, the cells were incubated by $\mathrm{IC}_{50}$ concentrations of these compounds for $24 \mathrm{~h}$ (Figures 4 and 5 and Table 3, respectively).
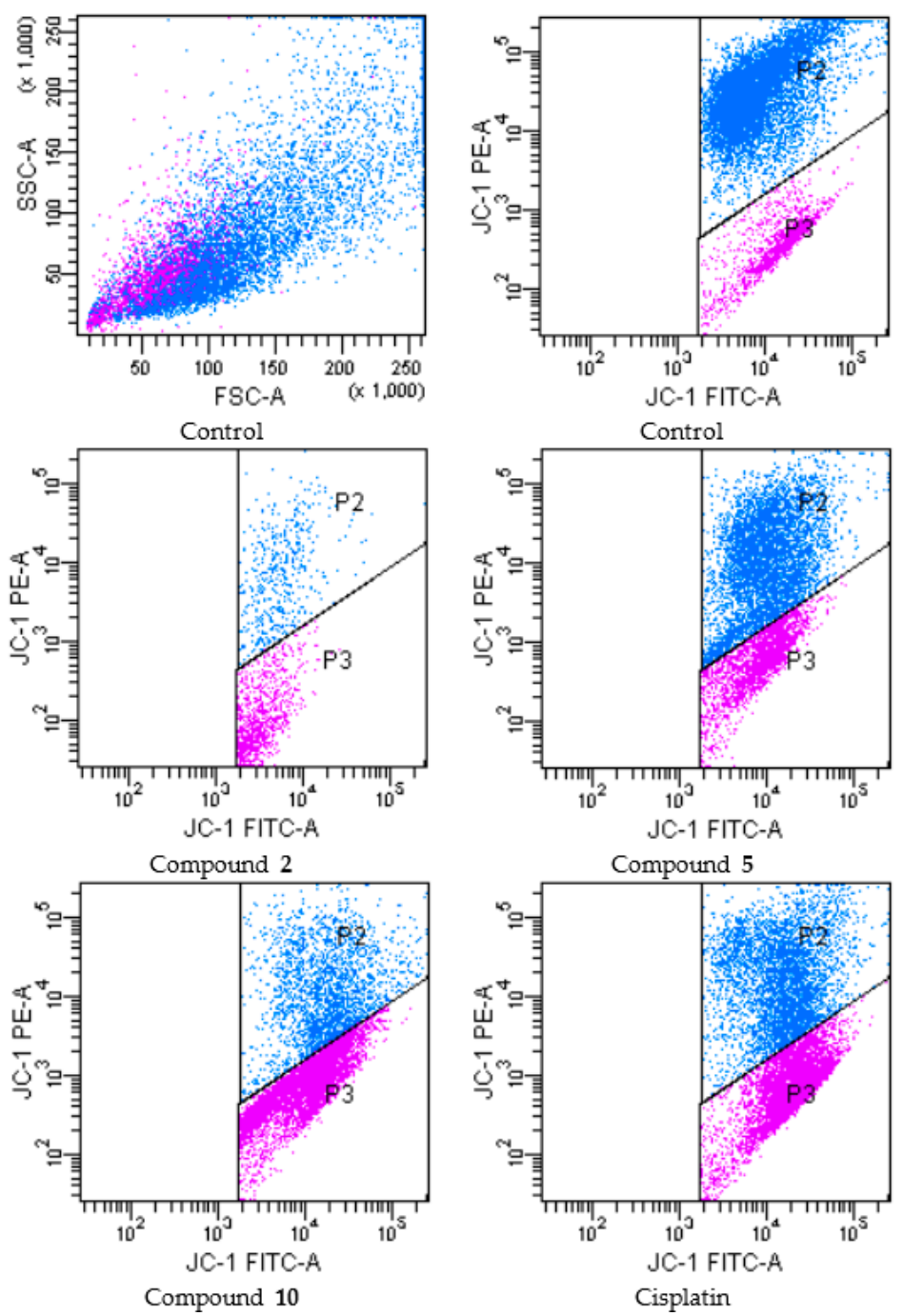

Figure 4. The reduction of the mitochondrial membrane potential in A549 cell line by the compounds. The cells treated or untreated with the $\mathrm{IC}_{50}$ doses of the compounds for $24 \mathrm{~h}$ were stained with the mitochondrial-selectivite JC-1 dye and analyzed by flow cytometry. P2: mitochondrial membrane polarized cells, P3: mitochondrial membrane depolarized cells. 

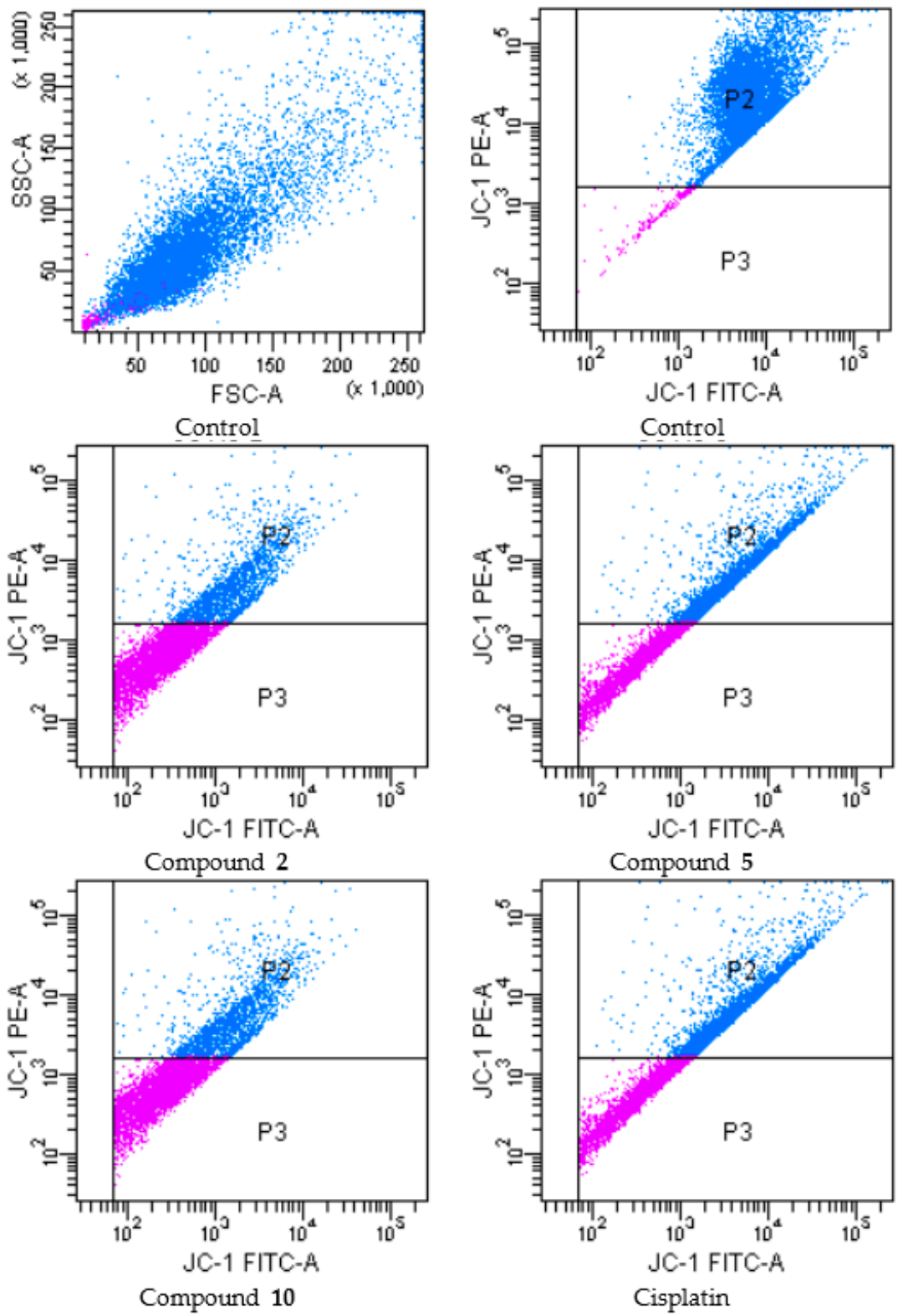

Figure 5. The reduction of the mitochondrial membrane potential in C6 cell line by the compounds. The cells treated or untreated with the $\mathrm{IC}_{50}$ doses of the compounds for $24 \mathrm{~h}$ were stained with the mitochondrial-selectivite JC-1 dye and analyzed by flow cytometry. P2: mitochondrial membrane polarized cells, P3: mitochondrial membrane depolarized cells.

Following flow cytometric analyses, mitochondrial membrane polarized cell percentages of compounds 2, 5, 10 and cisplatin (for $\mathrm{IC}_{50}$ doses) were determined as 4.5, 52.7, 21.9 and 41.4 respectively, while mitochondrial membrane depolarized cell percentages of compounds 2, 5, 10 and cisplatin (for $\mathrm{IC}_{50}$ doses) were determined as 9.8, 24.6, 57.9 and 54.0 respectively, on A549 cell line. On the other hand, mitochondrial membrane polarized cell percentages of compounds 2, 5, 10 and cisplatin (for $\mathrm{IC}_{50}$ doses) were determined as 44.8, 49.8, 35.1 and 46.6 respectively, while mitochondrial membrane depolarized cell percentages of compounds 2, 5, 10 and cisplatin (for $\mathrm{IC}_{50}$ doses) were determined as 21.1, 45.0, 63.7 and 48.4 respectively, on C6 cell line. According to these findings, compound 10 was the most effective agent for depolarization of mitochondrial membrane on both cell lines. Furthermore, compound 5 showed the similar effects on C6 glioma cell line compared to cisplatin. 
Table 3. The effects of the compounds on mitochondrial membrane potential of A549 and C6 cells for $24 \mathrm{~h}$.

\begin{tabular}{ccccc}
\hline \multirow{2}{*}{ Groups } & \multicolumn{2}{c}{ P2 (\%) } & \multicolumn{2}{c}{ P3 (\%) } \\
\cline { 2 - 5 } & C6 Cells & A549 Cells & C6 Cells & A549 Cells \\
\hline Control (untreated) & 98.3 & 82.6 & 1.7 & 13.1 \\
Compound 2 treated cells & 44.8 & 4.5 & 21.1 & 9.8 \\
Compound 5 treated cells & 49.8 & 52.7 & 45.0 & 24.6 \\
Compound 10 treated cells & 35.1 & 21.9 & 63.7 & 57.9 \\
Cisplatin treated cells & 46.6 & 41.4 & 48.4 & 54.0 \\
\hline
\end{tabular}

\subsubsection{Evaluation of $\mathrm{AChE}$ and BuChE Inhibition}

The anticholinesterase effects of all compounds on $\mathrm{AChE}$ and BuChE were determined by a modification of Ellman's spectrophotometric method (Table 4). The tested compounds were more effective against $\mathrm{AChE}$ than BuChE. Among these compounds, the most effective AChE inhibitor was found as compound $10\left(\mathrm{IC}_{50}=108.0 \pm 3.53 \mu \mathrm{M}\right)$ followed by compound $\mathbf{9}\left(\mathrm{IC}_{50}=205.0 \pm 5.0 \mu \mathrm{M}\right)$ when compared with galantamine $\left(\mathrm{IC}_{50}=1.83 \pm 0.21 \mu \mathrm{M}\right)$. This outcome indicated that bromo substituted 1,3-benzodioxole ring increased the inhibitory activity against AChE. Compounds 3 and $\mathbf{5}$ did not show any inhibitory activity against $\mathrm{AChE}$, whereas other derivatives showed weak inhibition on AChE. On the other hand, compounds 7, 8 and 10 showed weak inhibition on BuChE, whilst other compounds were found to be inactive against BuChE.

Considering the difference between $\mathrm{IC}_{50}$ values of compounds 7 and $\mathbf{9}$, the introduction of chlorine atom into the 3 th position of benzene ring increased anticholinesterase activity against $\mathrm{AChE}$, whereas the introduction of chlorine atom into the 3th position of benzene ring decreased anticholinesterase activity against BuChE.

Compound 5, the most effective apoptotic derivative in this series against $\mathrm{C} 6$ rat glioma cells, did not show any ChE inhibitory activity. On the other hand, compound 10, the most potent anticholinesterase derivative in this series, did not exhibit significant anticancer activity against A549 and C 6 cell lines. In the current work, there is no direct relationship between anticancer activity and cholinesterases.

Table 4. The anticholinesterase activity of the compounds.

\begin{tabular}{ccc}
\hline \multirow{2}{*}{ Compound } & \multicolumn{2}{c}{ IC $_{50}(\mu \mathrm{M})$} \\
\cline { 2 - 3 } & AChE & BuChE \\
\hline $\mathbf{1}$ & $>267.25$ & --- \\
$\mathbf{2}$ & $>232.32$ & --- \\
$\mathbf{3}$ & --- & --- \\
$\mathbf{4}$ & $>233.68$ & --- \\
$\mathbf{5}$ & --- & --- \\
$\mathbf{6}$ & $>252.10$ & -- \\
$\mathbf{7}$ & $>239.67$ & $>239.67$ \\
$\mathbf{8}$ & $>211.51$ & $>211.51$ \\
$\mathbf{9}$ & $205.0 \pm 5.0$ & --- \\
$\mathbf{1 0}$ & $108.0 \pm 3.53$ & $>189.46$ \\
Galantamine & $1.83 \pm 0.21$ & $18.17 \pm 0.76$ \\
\hline \multicolumn{3}{c}{}
\end{tabular}

\subsubsection{Evaluation of Sirtuin-1 Activity}

The effects of compound 5 on sirtuin- 1 activity were determined by an ELISA Sirtuin- 1 activity kit (Table 5, Figure 6). According to the assay, compound 5 decreased SIRT1 levels in C6 rat glioma cells at $\mathrm{IC}_{50} / 2$ concentration. However, increasing the concentration of compound 5 caused elevated SIRT1 levels compared to control. These results showed that the effects of compound 5 on SIRT1 levels were dose dependent in C6 glioma cells. In different studies, inhibition of SIRT1 activity leads to elevated 
p53 acetylation and transactivation resulting in enhanced apoptosis and cytostasis. Hence, inhibition of SIRT1 levels seemed as beneficial for cancer treatment [14].

Table 5. The effects of compound 5 on SIRT1 Activity.

\begin{tabular}{cc}
\hline Compound & SIRT1 Concentration $(\mathrm{ng} / \mathrm{mL})$ \\
\hline Control & $3.12 \pm 0.03$ \\
Compound 5 a & $0.67 \pm 0.22$ \\
Compound 5 b & $3.82 \pm 0.08$ \\
Cisplatin a & $4.53 \pm 1.37$ \\
Cisplatin b & $3.32 \pm 1.41$ \\
\hline
\end{tabular}

a: $\mathrm{IC}_{50} / 2$ concentration; b: $\mathrm{IC}_{50}$ concentration.

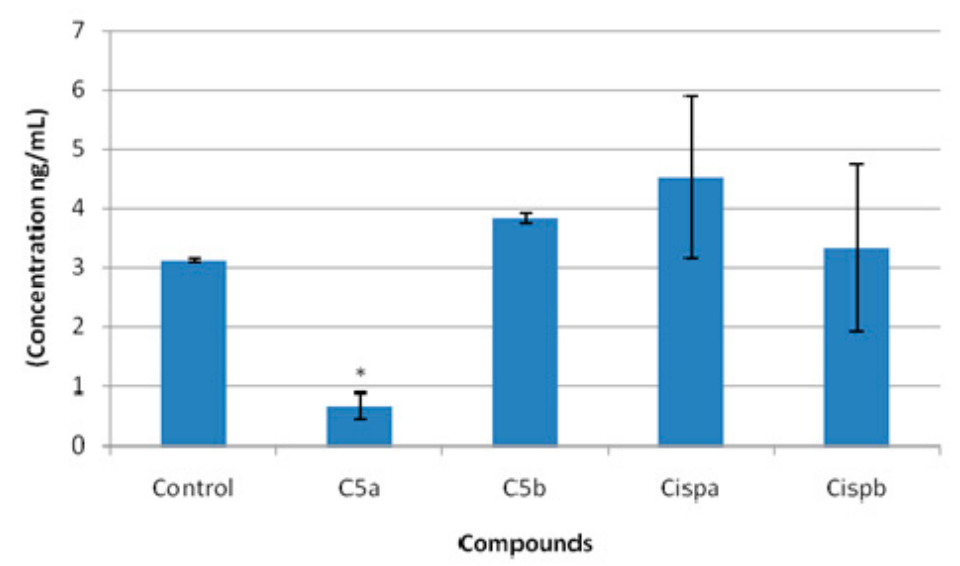

Figure 6. The effects of compound 5 on SIRT1 levels in C6 rat glioma cell line. a: $\mathrm{IC}_{50 / 2}$ concentration; b: $\mathrm{IC}_{50}$ concentration; ${ }^{*}$ significance from control group $p<0.05$.

\subsubsection{Docking Studies}

Docking studies were also performed for compound 5 on SIRT1 (PDB code: 4IG9). Compound 5 showed good affinity close to active site of the enzyme which was previously defined [12]. In Figure 7, the best docking position of compound 5 on SIRT1 and all interactions between compound 5 and SIRT1 are shown and described.
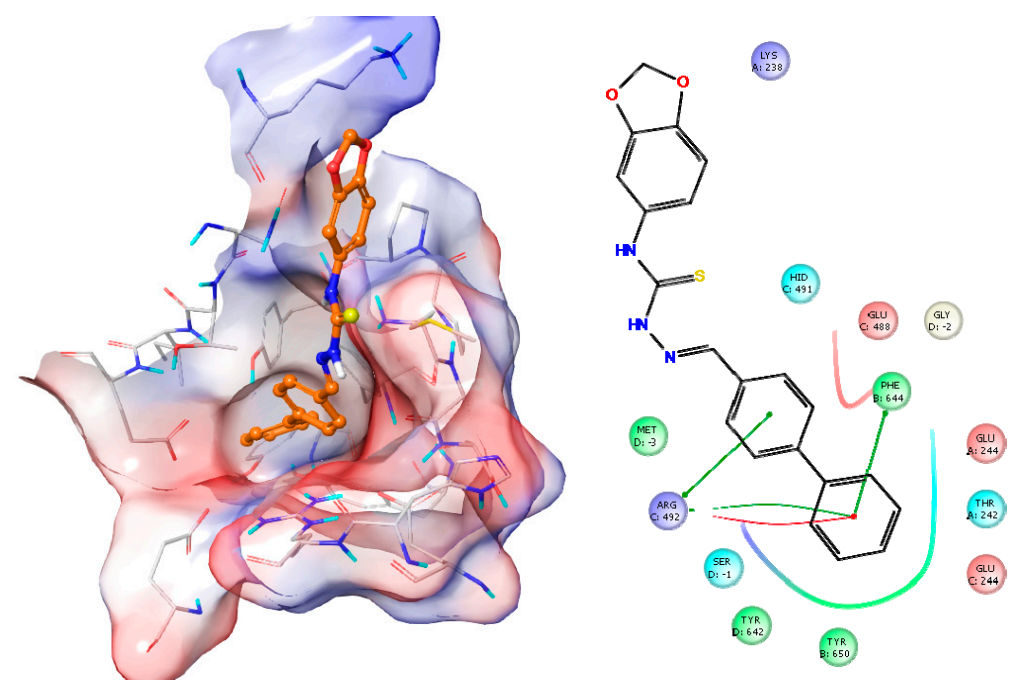

Figure 7. The docking position of compound 5 on SIRT1 and the interactions between compound 5 and SIRT1. (Green line: Pi-pi stacking; Red line: Salt bridge). Surface representation with overlaid electrostatic surface potentials (Red: Negative; Blue: Positive). 


\section{Materials and Methods}

\subsection{General Information}

All reagents were purchased from commercial suppliers and were used without further purification. Melting points (M.p.) were determined on an Electrothermal 9100 melting point apparatus (Weiss-Gallenkamp, Loughborough, UK) and are uncorrected. IR spectra were recorded on an IRPrestige-21 Fourier Transform Infrared spectrophotometer (Shimadzu, Tokyo, Japan). ${ }^{1} \mathrm{H}-\mathrm{NMR}$ and ${ }^{13} \mathrm{C}-\mathrm{NMR}$ spectra were recorded on a Varian Mercury-400 FT-NMR spectrometer (Agilent, Palo Alto, CA, USA). Mass spectra were recorded on an Agilent LC-MSD-Trap-SL Mass spectrometer (Agilent Technologies, Palo Alto, CA, USA). Elemental analyses were performed on a Perkin Elmer EAL 240 elemental analyzer (Perkin-Elmer, Norwalk, CT, USA) and the results were within $\pm 0.4 \%$ of the theoretical values.

\subsection{General Procedures for the Synthesis of the Compounds}

\subsubsection{4-(1,3-Benzodioxol-5-yl)thiosemicarbazide (A)}

A mixture of 1,3-benzodioxol-5-yl isothiocyanate $(0.1 \mathrm{~mol})$ and hydrazine hydrate $(0.2 \mathrm{~mol})$ in ethanol $(30 \mathrm{~mL})$ was stirred at room temperature for $4 \mathrm{~h}$ and then filtered. The residue was crystallized from ethanol.

\subsubsection{4-(1,3-Benzodioxol-5-yl)-1-[(aryl)methylene]thiosemicarbazides 1-10}

A mixture of 4-(1,3-benzodioxol-5-yl)thiosemicarbazide (A) (0.01 mol) and aromatic aldehydes $(0.01 \mathrm{~mol})$ was refluxed in ethanol for $8 \mathrm{~h}$, filtered and crystallized from ethanol.

4-(1,3-Benzodioxole-5-yl)-1-(benzylidene)thiosemicarbazide (1). Yield: $85 \%$. Mp $181.7^{\circ} \mathrm{C} . \mathrm{IR} v_{\max }\left(\mathrm{cm}^{-1}\right)$ : 3317.56 (N-H stretching), 3153.61 (aromatic C-H stretching), 2989.66 (aliphatic C-H stretching), $2883.58\left(\mathrm{O}-\mathrm{CH}_{2}\right.$ stretching), 1535.34, $1487.12(\mathrm{C}=\mathrm{N}, \mathrm{C}=\mathrm{C}$ stretching and $\mathrm{N}-\mathrm{H}$ bending), 1446.61, 1398.39, 1350.17 (C-H bending), 1278.81, 1188.15, 1126.43, 1103.28, 1062.78, 1035.77 (C-N stretching, $\mathrm{C}=\mathrm{S}$ stretching and aromatic $\mathrm{C}-\mathrm{H}$ in plane bending), 931.62, 891.11, 854.47, 812.03, 763.81, 750.31, 692.44, 661.58, 624.94 (aromatic C-H out of plane bending and C-S stretching). ${ }^{1} \mathrm{H}-\mathrm{NMR}(400 \mathrm{MHz}$, DMSO- $\left.d_{6}\right): 6.04\left(\mathrm{~s}, 2 \mathrm{H}, \mathrm{O}-\mathrm{CH}_{2}-\mathrm{O}\right), 6.90-6.97(\mathrm{~m}, 2 \mathrm{H}$, benzodioxole), 7.19 (s, 1H, benzodioxole), 7.40-7.45 (m, 3H, phenyl), 7.90-7.92 (m, 2H, phenyl), 8.18 (s, 1H, N=CH), $10.02(\mathrm{~s}, 1 \mathrm{H}, \mathrm{NH}), 11.82$ (s, 1H, NH). ${ }^{13} \mathrm{C}-\mathrm{NMR}$ (100 MHz, DMSO-d $)_{6}$ ) 101.26 (O-C-O), 107.36 (benzodioxole $\mathrm{C}_{4}$ ), 107.97 (benzodioxole $C_{7}$ ), 119.40 (benzodioxole $C_{6}$ ), 127.60 (phenyl $C_{3}$ and $C_{5}$ ), 128.62 (phenyl $C_{2}$ and $\mathrm{C}_{6}$ ), 129.99 (benzodioxole $\mathrm{C}_{5}$ ), 133.10 (phenyl $\mathrm{C}_{4}$ ), 134.04 (phenyl $\mathrm{C}_{1}$ ), 142.78 (benzodioxole $\mathrm{C}_{7 \mathrm{a}}$ ), 144.87 $(\mathrm{N}=\mathrm{C}), 146.59$ (benzodioxole $\left.\mathrm{C}_{3 \mathrm{a}}\right), 176.40(\mathrm{C}=\mathrm{S})$. MS (ESI) $(\mathrm{m} / \mathrm{z})$ : $[\mathrm{M}+\mathrm{H}]^{+}$300. Anal. Calcd. for $\mathrm{C}_{15} \mathrm{H}_{13} \mathrm{~N}_{3} \mathrm{O}_{2} \mathrm{~S}: \mathrm{C}, 60.19 ; \mathrm{H}, 4.38 ; \mathrm{N}, 14.04$. Found: $\mathrm{C}, 60.39 ; \mathrm{H}, 4.35 ; \mathrm{N}, 14.30$.

4-(1,3-Benzodioxole-5-yl)-1-(4-nitrobenzylidene)thiosemicarbazide (2). Yield: 95\%. Mp $233.1{ }^{\circ} \mathrm{C} . \mathrm{IR} v_{\max }$ $\left(\mathrm{cm}^{-1}\right)$ : 3327.21 (N-H stretching), 3153.61 (aromatic C-H stretching), 2995.45 (aliphatic C-H stretching), $2885.51\left(\mathrm{O}-\mathrm{CH}_{2}\right.$ stretching $), 1585.49,1334.74\left(\mathrm{NO}_{2}\right.$ stretching $), 1539.20,1496.76(\mathrm{C}=\mathrm{N}, \mathrm{C}=\mathrm{C}$ stretching and N-H bending), 1436.97 (C-H stretching), 1274.95, 1257.59, 1234.44, 1186.22, 1130.29, 1076.28, 1033.85 (C-N stretching, $\mathrm{C}=\mathrm{S}$ stretching and aromatic $\mathrm{C}-\mathrm{H}$ in plane bending), 935.48, 898.83, 854.47, 835.18, 808.17, 744.52, 690.52, 599.86 (aromatic C-H out of plane bending and C-S stretching). ${ }^{1} \mathrm{H}-\mathrm{NMR}$ (400 MHz, DMSO-d $d_{6}$ ): 6.06 (s, 2H, O-CH2-O), 6.93 (s, 2H, benzodioxole), 7.15 (s, 1H, benzodioxole), 8.17-8.25 (m, 5H, phenyl and $\mathrm{N}=\mathrm{CH}), 10.21$ (s, 1H, NH), 12.06 (s, 1H, NH). ${ }^{13} \mathrm{C}-\mathrm{NMR}(100 \mathrm{MHz}$, DMSO- $d_{6}$ ): 101.32 (O-C-O), 107.41 (benzodioxole $\mathrm{C}_{4}$ ), 108.10 (benzodioxole $\mathrm{C}_{7}$ ), 119.62 (benzodioxole $\mathrm{C}_{6}$ ), 123.70 (phenyl $\mathrm{C}_{3}$ and $\mathrm{C}_{5}$ ), 128.40 (phenyl $\mathrm{C}_{2}$ and $\mathrm{C}_{6}$ ), 132.92 (benzodioxole $\mathrm{C}_{5}$ ), 140.01 (phenyl $\mathrm{C}_{1}$ ), 140.55 (benzodioxole $\mathrm{C}_{7 \mathrm{a}}$ ), $145.06(\mathrm{~N}=\mathrm{C}), 146.66$ (benzodioxole $\mathrm{C}_{3 \mathrm{a}}$ ), 147.63 (phenyl $\mathrm{C}_{4}$ ), 176.83 
$(C=S)$. MS (ESI) $(m / z):[\mathrm{M}+\mathrm{H}]^{+}$345. Anal. Calcd. for $\mathrm{C}_{15} \mathrm{H}_{12} \mathrm{~N}_{4} \mathrm{O}_{4} \mathrm{~S}: \mathrm{C}, 52.32 ; \mathrm{H}, 3.51 ; \mathrm{N}, 16.27$. Found: C, 52.22; H, 3.46; N, 16.08 .

4-(1,3-Benzodioxole-5-yl)-1-(4-cyanobenzylidene)thiosemicarbazide (3). Yield: $90 \%$. Mp $224.1{ }^{\circ} \mathrm{C}$. IR $v_{\max }$ $\left(\mathrm{cm}^{-1}\right)$ : 3309.85 (N-H stretching), 3142.04 (aromatic C-H stretching), 2981.95 (aliphatic C-H stretching), 2891.30 (O- $\mathrm{CH}_{2}$ stretching), 2223.92 ( $\mathrm{C} \equiv \mathrm{N}$ stretching), 1541.12, 1498.69, 1485.19 (C=N, $\mathrm{C}=\mathrm{C}$ stretching and $\mathrm{N}-\mathrm{H}$ bending), 1433.11, 1411.89 (C-H bending), 1298.09, 1253.73, 1215.15, 1180.44, 1138.00, 1082.07, 1031.92 (C-N stretching, $\mathrm{C}=\mathrm{S}$ stretching and aromatic $\mathrm{C}-\mathrm{H}$ in plane bending), 923.90, 889.18, 854.47, 862.18, 827.46, 792.74, 731.02, 661.58, 694.37, 599.86 (aromatic C-H out of plane bending and C-S stretching). ${ }^{1} \mathrm{H}-\mathrm{NMR}\left(400 \mathrm{MHz}, \mathrm{DMSO}-d_{6}\right): 6.06\left(\mathrm{~s}, 2 \mathrm{H}, \mathrm{O}-\mathrm{CH}_{2}-\mathrm{O}\right), 6.93(\mathrm{~s}, 2 \mathrm{H}$, benzodioxole), $7.17(\mathrm{~s}, 1 \mathrm{H}$, benzodioxole), $7.87(\mathrm{~d}, J=8.4 \mathrm{~Hz}, 2 \mathrm{H}$, phenyl), $8.11(\mathrm{~d}, J=8.8 \mathrm{~Hz}, 2 \mathrm{H}$, phenyl), 8.19 $(\mathrm{s}, 1 \mathrm{H}, \mathrm{N}=\mathrm{CH}), 10.17(\mathrm{~s}, 1 \mathrm{H}, \mathrm{NH}), 12.03(\mathrm{~s}, 1 \mathrm{H}, \mathrm{NH}) .{ }^{13} \mathrm{C}-\mathrm{NMR}\left(100 \mathrm{MHz}, \mathrm{DMSO}-d_{6}\right): 101.32$ (O-C-O), 107.40 (benzodioxole $\mathrm{C}_{4}$ ), 108.12 (benzodioxole $\mathrm{C}_{7}$ ), $111.67(\mathrm{C} \equiv \mathrm{N}), 118.79$ (benzodioxole $\mathrm{C}_{6}$ ), 119.60 (phenyl $C_{3}$ and $C_{5}$ ), 128.06 (phenyl $C_{2}$ and $C_{6}$ ), 132.41 (benzodioxole $C_{5}$ ), 132.93 (phenyl $C_{1}$ ), 138.59 (benzodioxole $\mathrm{C}_{7 \mathrm{a}}$ ), $140.54(\mathrm{~N}=\mathrm{C}), 145.05$ (benzodioxole $\mathrm{C}_{3 \mathrm{a}}$ ), 146.66 (phenyl $\mathrm{C}_{4}$ ), $176.75(\mathrm{C}=\mathrm{S})$. MS (ESI) $(\mathrm{m} / \mathrm{z}):[\mathrm{M}+\mathrm{H}]^{+}$325. Anal. Calcd. for $\mathrm{C}_{16} \mathrm{H}_{12} \mathrm{~N}_{4} \mathrm{O}_{2} \mathrm{~S}: \mathrm{C}, 59.25 ; \mathrm{H}, 3.73 ; \mathrm{N}$, 17.27. Found: $\mathrm{C}, 60.41 ; \mathrm{H}, 3.75$; $\mathrm{N}, 17.41$.

4-(1,3-Benzodioxole-5-yl)-1-(4-dimethylaminobenzylidene)thiosemicarbazide (4). Yield: 80\%. Mp $208.6{ }^{\circ} \mathrm{C}$. IR $v_{\max }\left(\mathrm{cm}^{-1}\right)$ : 3282.84 (N-H stretching), 3140.11 (aromatic C-H stretching), 2987.74 (aliphatic C-H stretching), 2881.65 (O- $\mathrm{CH}_{2}$ stretching), 1597.06, 1550.77, 1523.76, 1498.69, 1487.12 (C=N, C=C stretching and N-H bending), 1452.40, 1431.18, 1365.60, 1350.17 (C-H bending), 1294.24, 1257.59, 1219.01, 1184.29, 1165.00, 1132.21, 1033.85 (C-N stretching, $\mathrm{C}=\mathrm{S}$ stretching and aromatic $\mathrm{C}-\mathrm{H}$ in plane bending), 933.55, 842.89, 813.96, 794.67, 752.24, 709.80, 653.87 (aromatic C-H out of plane bending and C-S stretching). ${ }^{1} \mathrm{H}-\mathrm{NMR}\left(400 \mathrm{MHz}\right.$, DMSO- $\left.d_{6}\right): 2.95\left(\mathrm{~s}, 6 \mathrm{H}, \mathrm{N}\left(\mathrm{CH}_{3}\right)_{2}\right), 6.03\left(\mathrm{~s}, 2 \mathrm{H}, \mathrm{O}-\mathrm{CH}_{2}-\mathrm{O}\right), 6.71(\mathrm{~d}, J=8.8 \mathrm{~Hz}, 2 \mathrm{H}$, phenyl), $6.89\left(\mathrm{~d}, J=8.4 \mathrm{~Hz}, 1 \mathrm{H}\right.$, benzodioxole), $6.96\left(\mathrm{dd}, J_{1}=8.0 \mathrm{~Hz}\right.$ and $J_{2}=2 \mathrm{~Hz}, 1 \mathrm{H}$, benzodioxole), $7.22(\mathrm{~d}, J=1.6 \mathrm{~Hz}, 1 \mathrm{H}$, benzodioxole), $7.69(\mathrm{~d}, J=8.8 \mathrm{~Hz}, 2 \mathrm{H}$, phenyl), 8.05 (s, 1H, N=CH), 9.81 $(\mathrm{s}, 1 \mathrm{H}, \mathrm{NH}), 11.56(\mathrm{~s}, 1 \mathrm{H}, \mathrm{NH}) .{ }^{13} \mathrm{C}-\mathrm{NMR}\left(100 \mathrm{MHz}, \mathrm{DMSO}-d_{6}\right): 39.74\left(2 \mathrm{CH}_{3}\right), 101.19(\mathrm{O}-\mathrm{C}-\mathrm{O}), 107.30$ (benzodioxole $\mathrm{C}_{4}$ ), 107.66 (benzodioxole $\mathrm{C}_{7}$ ), 111.59 (phenyl $\mathrm{C}_{3}$ and $\mathrm{C}_{5}$ ), 118.99 (benzodioxole $\mathrm{C}_{6}$ ), 121.18 (phenyl $\mathrm{C}_{1}$ ), 128.98 (phenyl $\mathrm{C}_{2}$ and $\mathrm{C}_{6}$ ), 133.27 (benzodioxole $\mathrm{C}_{5}$ ), 143.87 (benzodioxole $\mathrm{C}_{7 \mathrm{a}}$ ), $144.61(\mathrm{~N}=\mathrm{C}), 146.51$ (benzodioxole $\mathrm{C}_{3 \mathrm{a}}$ ), 151.47 (phenyl $\mathrm{C}_{4}$ ), $175.27(\mathrm{C}=\mathrm{S})$. MS (ESI) $(\mathrm{m} / \mathrm{z}):[\mathrm{M}+\mathrm{H}]^{+} 343$. Anal. Calcd. for $\mathrm{C}_{17} \mathrm{H}_{18} \mathrm{~N}_{4} \mathrm{O}_{2} \mathrm{~S}$ : C, 59.63; H, 5.30; N, 16.36. Found: $\mathrm{C}, 59.60 ; \mathrm{H}, 5.27 ; \mathrm{N}, 16.36$.

4-(1,3-Benzodioxole-5-yl)-1-[(biphenyl-4-yl)methylene]thiosemicarbazide (5). Yield: 90\%. Mp $195.7{ }^{\circ} \mathrm{C}$. IR $v_{\max }\left(\mathrm{cm}^{-1}\right)$ : 3321.42 (N-H stretching), 3130.47 (aromatic C-H stretching), 2980.02 (aliphatic C-H stretching), $2887.44\left(\mathrm{O}-\mathrm{CH}_{2}\right.$ stretching $), 1600.92,1531.48,1502.55,1485.19(\mathrm{C}=\mathrm{N}, \mathrm{C}=\mathrm{C}$ stretching and $\mathrm{N}-\mathrm{H}$ bending), 1440.83, 1354.03 (C-H bending), 1273.02, 1246.02, 1209.37, 1184.29, 1122.57, 1066.64, 1029.99 (C-N stretching, $\mathrm{C}=\mathrm{S}$ stretching and aromatic $\mathrm{C}-\mathrm{H}$ in plane bending), 921.97, 840.96, 771.53, 727.16, 702.09, 638.44 (aromatic C-H out of plane bending and C-S stretching). ${ }^{1} \mathrm{H}-\mathrm{NMR}(400 \mathrm{MHz}$, DMSO- $\left.d_{6}\right): 6.06\left(\mathrm{~s}, 2 \mathrm{H}, \mathrm{O}-\mathrm{CH}_{2}-\mathrm{O}\right), 6.93\left(\mathrm{~d}, J=8.4 \mathrm{~Hz}, 1 \mathrm{H}\right.$, benzodioxole), $7.00\left(\mathrm{dd}, J_{1}=8.0 \mathrm{~Hz}\right.$, $J_{2}=1.6 \mathrm{~Hz}, 1 \mathrm{H}$, benzodioxole), $7.24(\mathrm{~d}, J=1.6 \mathrm{~Hz}, 1 \mathrm{H}$, benzodioxole $), 7.39(\mathrm{t}, J=7.2 \mathrm{~Hz}, 1 \mathrm{H}$, phenyl), $7.48(\mathrm{t}, J=7.6 \mathrm{~Hz}, 2 \mathrm{H}$, phenyl), $7.74(\mathrm{t}, J=7.6 \mathrm{~Hz}, 4 \mathrm{H}$, phenyl), $8.02(\mathrm{~d}, J=8.4 \mathrm{~Hz}, 2 \mathrm{H}$, phenyl), $8.26(\mathrm{~s}, 1 \mathrm{H}$, $\mathrm{N}=\mathrm{CH}), 10.11(\mathrm{~s}, 1 \mathrm{H}, \mathrm{NH}), 11.92(\mathrm{~s}, 1 \mathrm{H}, \mathrm{NH}) .{ }^{13} \mathrm{C}-\mathrm{NMR}(100 \mathrm{MHz})\left(\mathrm{DMSO}-d_{6}\right) \delta(\mathrm{ppm}): 101.68\left(\mathrm{CH}_{2}\right)$, $107.79(\mathrm{CH}), 108.49(\mathrm{CH}), 119.93(\mathrm{CH}), 127.13(2 \mathrm{CH}), 127.25(\mathrm{CH}), 128.29(2 \mathrm{CH}), 129.44(2 \mathrm{CH}), 133.53$ (CH), $133.61(\mathrm{CH}), 139.79(2 \mathrm{C}), 141.85(\mathrm{CH}), 142.71(\mathrm{C}), 145.28(2 \mathrm{C}), 146.97(\mathrm{C}), 176.72(\mathrm{C}) . \mathrm{MS}(\mathrm{ESI})$ $(m / z):[\mathrm{M}+\mathrm{H}]^{+}$376. Anal. Calcd. for $\mathrm{C}_{21} \mathrm{H}_{17} \mathrm{~N}_{3} \mathrm{O}_{2} \mathrm{~S}: \mathrm{C}, 67.18 ; \mathrm{H}, 4.56 ; \mathrm{N}, 11.19$. Found: $\mathrm{C}, 67.35 ; \mathrm{H}, 4.59$; $\mathrm{N}, 11.05$.

4-(1,3-Benzodioxole-5-yl)-1-(4-fluorobenzylidene)thiosemicarbazide (6). Yield: 90\%. Mp $196.8^{\circ} \mathrm{C}$. IR $v_{\max }$ $\left(\mathrm{cm}^{-1}\right)$ : 3219.19 (N-H stretching), 3118.90 (aromatic C-H stretching), 2981.95 (aliphatic C-H stretching), 2900.94 ( $\mathrm{O}-\mathrm{CH}_{2}$ stretching), 1598.99, 1537.27, 1502.55, 1489.05 (C=N, C=C stretching and N-H bending), 
1444.68, 1355.96 (C-H bending), 1228.66, 1211.30, 1188.15, 1157.29, 1072.42, 1037.70 (C-N stretching, $\mathrm{C}=\mathrm{S}$ stretching and aromatic $\mathrm{C}-\mathrm{H}$ in plane bending), 937.40, 856.39, 835.18, 810.10, 790.81, 738.74, 711.73, 651.94, 596.00 (aromatic C-H out of plane bending and C-S stretching). ${ }^{1} \mathrm{H}-\mathrm{NMR}$ (400 MHz, DMSO- $d_{6}$ ): $6.05\left(\mathrm{~s}, 2 \mathrm{H}, \mathrm{O}-\mathrm{CH}_{2}-\mathrm{O}\right), 6.90-6.95(\mathrm{~m}, 2 \mathrm{H}$, benzodioxole), $7.17(\mathrm{~s}, 1 \mathrm{H}$, benzodioxole), $7.26(\mathrm{t}, J=8.8 \mathrm{~Hz}$, 2H, phenyl), $7.99\left(\mathrm{~m}, 2 \mathrm{H}\right.$, phenyl), $8.16(\mathrm{~s}, 1 \mathrm{H}, \mathrm{N}=\mathrm{CH}), 10.04(\mathrm{~s}, 1 \mathrm{H}, \mathrm{NH}), 11.81(\mathrm{~s}, 1 \mathrm{H}, \mathrm{NH}) .{ }^{13} \mathrm{C}-\mathrm{NMR}$ (100 MHz, DMSO- $d_{6}$ ): 101.26 (O-C-O), 107.35 (benzodioxole $\mathrm{C}_{4}$ ), 108.03 (benzodioxole $\mathrm{C}_{7}$ ), 115.64 $\left(\mathrm{d}, J=21.3 \mathrm{~Hz}\right.$, phenyl $\mathrm{C}_{3}$ and $\left.\mathrm{C}_{5}\right), 119.45$ (benzodioxole $\left.\mathrm{C}_{6}\right), 129.81\left(\mathrm{~d}, J=8.4 \mathrm{~Hz}\right.$, phenyl $\mathrm{C}_{2}$ and $\mathrm{C}_{6}$ ), $130.68\left(\mathrm{~d}, J=3.0 \mathrm{~Hz}\right.$, benzodioxole $\left.\mathrm{C}_{5}\right), 133.09$ (phenyl $\left.\mathrm{C}_{1}\right), 141.57$ (benzodioxole $\mathrm{C}_{7 \mathrm{a}}$ ), $144.89(\mathrm{~N}=\mathrm{C})$, 146.59 (benzodioxole $\mathrm{C}_{3 \mathrm{a}}$ ), 164.36 (phenyl $\left.\mathrm{C}_{4}\right), 176.41(\mathrm{C}=\mathrm{S})$. MS (ESI) $(\mathrm{m} / \mathrm{z})$ : $[\mathrm{M}+\mathrm{H}]^{+}$318. Anal. Calcd. for $\mathrm{C}_{15} \mathrm{H}_{12} \mathrm{FN}_{3} \mathrm{O}_{2} \mathrm{~S}: \mathrm{C}, 56.77 ; \mathrm{H}, 3.81 ; \mathrm{N}, 13.24$. Found: $\mathrm{C}, 56.76 ; \mathrm{H}, 3.42 ; \mathrm{N}, 5.98$.

4-(1,3-Benzodioxole-5-yl)-1-(4-chlorobenzylidene)thiosemicarbazide (7). Yield: 80\%. Mp 201.4 ${ }^{\circ} \mathrm{C}$. IR $v_{\max }$ $\left(\mathrm{cm}^{-1}\right)$ : 3344.57 (N-H stretching), 3138.18 (aromatic C-H stretching), 2981.95 (aliphatic C-H stretching), 2895.15 (O- $\mathrm{CH}_{2}$ stretching), 1595.13, 1539.20, 1508.33, 1485.19 (C=N, C=C stretching and N-H bending), 1446.61, 1402.25, 1352.10 (C-H bending), 1278.81, 1253.73, 1228.66, 1186.22, 1083.99, 1035.77, 1010.70 (C-N stretching, $\mathrm{C}=\mathrm{S}$ stretching and aromatic $\mathrm{C}-\mathrm{H}$ in plane bending), 933.55, 893.04, 846.75, 812.03, 752.24, 659.66, 605.65 (aromatic C-H out of plane bending and C-S stretching). ${ }^{1} \mathrm{H}-\mathrm{NMR}(400 \mathrm{MHz}$, DMSO- $\left.d_{6}\right): 6.05\left(\mathrm{~s}, 2 \mathrm{H}, \mathrm{O}-\mathrm{CH}_{2}-\mathrm{O}\right), 6.90-6.96(\mathrm{~m}, 2 \mathrm{H}$, benzodioxole), $7.16(\mathrm{~s}, 1 \mathrm{H}$, benzodioxole), 7.48 $(\mathrm{d}, J=8.4 \mathrm{~Hz}, 2 \mathrm{H}$, phenyl), $7.95(\mathrm{~d}, J=8.8 \mathrm{~Hz}, 2 \mathrm{H}$, phenyl), $8.14(\mathrm{~s}, 1 \mathrm{H}, \mathrm{N}=\mathrm{CH}), 10.07(\mathrm{~s}, 1 \mathrm{H}, \mathrm{NH})$, $11.86(\mathrm{~s}, 1 \mathrm{H}, \mathrm{NH}) .{ }^{13} \mathrm{C}-\mathrm{NMR}\left(100 \mathrm{MHz}, \mathrm{DMSO}-d_{6}\right): 101.26$ (O-C-O), 107.35 (benzodioxole $\left.\mathrm{C}_{4}\right), 108.04$ (benzodioxole $\mathrm{C}_{7}$ ), 119.48 (benzodioxole $\mathrm{C}_{6}$ ), 128.65 (phenyl $\mathrm{C}_{3}$ and $\mathrm{C}_{5}$ ), 129.21 (phenyl $\mathrm{C}_{2}$ and $\mathrm{C}_{6}$ ), 133.02 (benzodioxole $C_{5}$ ), 133.05 (phenyl $C_{1}$ ), 134.43 (phenyl $C_{4}$ ), 141.34 (benzodioxole $C_{7 a}$ ), 144.91 $(\mathrm{N}=\mathrm{C}), 146.59$ (benzodioxole $\left.\mathrm{C}_{3 \mathrm{a}}\right), 176.48(\mathrm{C}=\mathrm{S})$. MS (ESI) $(\mathrm{m} / \mathrm{z})$ : $[\mathrm{M}+\mathrm{H}]^{+}$334. Anal. Calcd. for $\mathrm{C}_{15} \mathrm{H}_{12} \mathrm{ClN}_{3} \mathrm{O}_{2} \mathrm{~S}: \mathrm{C}, 53.98 ; \mathrm{H}, 3.62 ; \mathrm{N}, 12.59: \mathrm{C}, 53.82 ; \mathrm{H}, 3.50 ; \mathrm{N}, 10.75$.

4-(1,3-Benzodioxole-5-yl)-1-(4-bromobenzylidene)thiosemicarbazide (8). Yield: $82 \%$. Mp $196.3^{\circ} \mathrm{C}$. IR $v_{\max }$ $\left(\mathrm{cm}^{-1}\right)$ : 3340.71 (N-H stretching), 3138.18 (aromatic C-H stretching), 2981.95 (aliphatic C-H stretching), 2895.15 ( $\mathrm{O}-\mathrm{CH}_{2}$ stretching), 1589.34, 1537.27, 1485.19 (C=N, C=C stretching and $\mathrm{N}-\mathrm{H}$ bending), 1446.61, 1398.39, 1354.03 (C-H bending), 1280.73, 1253.73, 1236.37, 1186.22, 1126.43, 1066.64, 1035.77, 1004.91 (C-N stretching, $\mathrm{C}=\mathrm{S}$ stretching and aromatic $\mathrm{C}-\mathrm{H}$ in plane bending), 933.55, 893.04, 864.11, 844.82, 812.03, 752.24, 659.66, 601.79 (aromatic C-H out of plane bending and C-S stretching). ${ }^{1} \mathrm{H}-\mathrm{NMR}$ (400 MHz, DMSO- $d_{6}$ ): 6.05 (s, 2H, O- $\left.\mathrm{CH}_{2}-\mathrm{O}\right), 6.91$ (s, 2H, benzodioxole), 7.13 (s, 1H, benzodioxole), $7.61(\mathrm{~d}, J=8.8 \mathrm{~Hz}, 2 \mathrm{H}$, phenyl), $7.87(\mathrm{~d}, J=8.8 \mathrm{~Hz}, 2 \mathrm{H}$, phenyl), $8.11(\mathrm{~s}, 1 \mathrm{H}, \mathrm{N}=\mathrm{CH}), 10.06(\mathrm{~s}, 1 \mathrm{H}$, $\mathrm{NH}), 11.84(\mathrm{~s}, 1 \mathrm{H}, \mathrm{NH}) .{ }^{13} \mathrm{C}-\mathrm{NMR}\left(100 \mathrm{MHz}, \mathrm{DMSO}-d_{6}\right)$ : 101.24 (O-C-O), 107.34 (benzodioxole $\mathrm{C}_{4}$ ), 108.04 (benzodioxole $\mathrm{C}_{7}$ ), 119.50 (benzodioxole $\mathrm{C}_{6}$ ), 123.22 (phenyl $\mathrm{C}_{4}$ ), 129.46 (phenyl $\mathrm{C}_{3}$ and $\mathrm{C}_{5}$ ), 131.55 (phenyl $C_{2}$ and $C_{6}$ ), 133.03 (benzodioxole $C_{5}$ ), 133.37 (phenyl $C_{1}$ ), 141.40 (benzodioxole $C_{7 a}$ ), $144.89(\mathrm{~N}=\mathrm{C}), 146.56$ (benzodioxole $\left.\mathrm{C}_{3 \mathrm{a}}\right), 176.47(\mathrm{C}=\mathrm{S})$. MS (ESI) $(\mathrm{m} / \mathrm{z})$ : $[\mathrm{M}+\mathrm{H}]^{+}$379. Anal. Calcd. for $\mathrm{C}_{15} \mathrm{H}_{12} \mathrm{BrN}_{3} \mathrm{O}_{2} \mathrm{~S}: \mathrm{C}, 47.63 ; \mathrm{H}, 3.20 ; \mathrm{N}, 11.11$. Found: $\mathrm{C}, 47.06 ; \mathrm{H}, 3.37 ; \mathrm{N}, 11.29$.

4-(1,3-Benzodioxole-5-yl)-1-(3,4-dichlorobenzylidene)thiosemicarbazide (9). Yield: 83\%. Mp $213.2{ }^{\circ} \mathrm{C}$. IR $v_{\max }$ $\left(\mathrm{cm}^{-1}\right)$ : 3228.84 (N-H stretching), 3128.54 (aromatic C-H stretching), 2981.95 (aliphatic C-H stretching), 2889.37 $\left(\mathrm{O}-\mathrm{CH}_{2}\right.$ stretching), 1510.26, 1489.05, $1463.97(\mathrm{C}=\mathrm{N}, \mathrm{C}=\mathrm{C}$ stretching and $\mathrm{N}-\mathrm{H}$ bending), 1438.90, 1398.39 (C-H bending), 1249.87, 1222.87, 1186.22, 1128.36, 1076.28, 1037.70 (C-N stretching, C=S stretching and aromatic $\mathrm{C}-\mathrm{H}$ in plane bending), 937.40, 866.04, 815.89, 721.38, 661.58, 601.79 (aromatic C-H out of plane bending and C-S stretching). ${ }^{1} \mathrm{H}-\mathrm{NMR}\left(400 \mathrm{MHz}, \mathrm{DMSO}-d_{6}\right): 6.06\left(\mathrm{~s}, 2 \mathrm{H}, \mathrm{O}-\mathrm{CH}_{2}-\mathrm{O}\right)$, 6.90-6.95 (m, 2H, benzodioxole), $7.13(\mathrm{~d}, J=1.6 \mathrm{~Hz}, 1 \mathrm{H}$, benzodioxole), $7.66(\mathrm{~d}, J=8.8 \mathrm{~Hz}, 1 \mathrm{H}$, phenyl), $7.80(\mathrm{dd}, J=8.4 \mathrm{~Hz}$ and $J=2 \mathrm{~Hz}, 1 \mathrm{H}$, phenyl), $8.11(\mathrm{~s}, 1 \mathrm{H}, \mathrm{N}=\mathrm{CH}), 8.34(\mathrm{~d}, J=2 \mathrm{~Hz}, 1 \mathrm{H}$, phenyl), 10.16 $(\mathrm{s}, 1 \mathrm{H}, \mathrm{NH}), 11.93(\mathrm{~s}, 1 \mathrm{H}, \mathrm{NH}) .{ }^{13} \mathrm{C}-\mathrm{NMR}\left(100 \mathrm{MHz}, \mathrm{DMSO}-d_{6}\right)$ : 101.28 (O-C-O), 107.37 (benzodioxole $\mathrm{C}_{4}$ ), 108.34 (benzodioxole $\mathrm{C}_{7}$ ), 119.85 (benzodioxole $\mathrm{C}_{6}$ ), 128.03 (phenyl $\mathrm{C}_{5}$ ), 128.32 (phenyl $\mathrm{C}_{3}$ ), 130.69 (phenyl $\mathrm{C}_{6}$ ), 131.80 (phenyl $\mathrm{C}_{2}$ ), 132.03 (benzodioxole $\mathrm{C}_{5}$ ), 132.99 (phenyl $\mathrm{C}_{1}$ ), 134.91 (phenyl $\mathrm{C}_{4}$ ), 139.95 (benzodioxole $\mathrm{C}_{7 \mathrm{a}}$ ), $145.05(\mathrm{~N}=\mathrm{C}), 146.62$ (benzodioxole $\mathrm{C}_{3 \mathrm{a}}$ ), $176.73(\mathrm{C}=\mathrm{S})$. MS (ESI) $(\mathrm{m} / \mathrm{z})$ : 
$[\mathrm{M}+\mathrm{H}]^{+}$369. Anal. Calcd. for $\mathrm{C}_{15} \mathrm{H}_{11} \mathrm{Cl}_{2} \mathrm{~N}_{3} \mathrm{O}_{2} \mathrm{~S}: \mathrm{C}, 48.93 ; \mathrm{H}, 3.01 ; \mathrm{N}, 11.41$. Found: $\mathrm{C}, 48.48 ; \mathrm{H}, 3.00$; $\mathrm{N}, 11.51$.

4-(1,3-Benzodioxole-5-yl)-1-(6-bromo-1,3-benzodioxole-5-yl)methylene)thiosemicarbazide (10). Yield: 85\%. Mp 219.1 ${ }^{\circ} \mathrm{C}$. IR $v_{\max }\left(\mathrm{cm}^{-1}\right)$ : $3224.98(\mathrm{~N}-\mathrm{H}$ stretching), 3161.33, 3030.17 (aromatic C-H stretching), $2908.65\left(\mathrm{O}-\mathrm{CH}_{2}\right.$ stretching), 1531.48, 1504.48, 1469.76 (C=N, C=C stretching and $\mathrm{N}-\mathrm{H}$ bending), 1444.68, 1419.61 (C-H bending), 1247.94, 1220.94, 1209.37, 1178.51, 1120.64, 1074.35, 1033.85 (C-N stretching, $\mathrm{C}=\mathrm{S}$ stretching and aromatic $\mathrm{C}-\mathrm{H}$ in plane bending), 933.55, 879.54, 848.68, 798.53, 746.45, 721.38, 682.80, 632.65, 605.65 (aromatic C-H out of plane bending and C-S stretching). ${ }^{1} \mathrm{H}-\mathrm{NMR}$ (400 MHz, DMSO- $d_{6}$ ): $6.05\left(\mathrm{~s}, 2 \mathrm{H}, \mathrm{O}-\mathrm{CH}_{2}-\mathrm{O}\right), 6.13\left(\mathrm{~s}, 2 \mathrm{H}, \mathrm{O}-\mathrm{CH}_{2}-\mathrm{O}\right), 6.80-6.95(\mathrm{~m}, 2 \mathrm{H}$, benzodioxole), $7.11(\mathrm{~d}, J=2 \mathrm{~Hz}, 1 \mathrm{H}$, benzodioxole), $7.24(\mathrm{~s}, 1 \mathrm{H}$, benzodioxole), $8.10(\mathrm{~s}, 1 \mathrm{H}, \mathrm{N}=\mathrm{CH}), 8.45(\mathrm{~s}, 1 \mathrm{H}$, benzodioxole), $10.08(\mathrm{~s}, 1 \mathrm{H}$, $\mathrm{NH}), 11.87$ (s, 1H, NH). ${ }^{13} \mathrm{C}-\mathrm{NMR}\left(100 \mathrm{MHz}, \mathrm{DMSO}-d_{6}\right): 101.25$ (O-C-O), 102.42 (O-C-O), 106.73 (benzodioxole $\mathrm{C}_{4}$ ), 107.30 (benzodioxole $\mathrm{C}_{4}$ ), 108.26 (benzodioxole $\mathrm{C}_{7}$ ), 112.32 (benzodioxole $\mathrm{C}_{7}$ ), 115.93 (benzodioxole $C_{6}$ ), 119.71 (benzodioxole $C_{6}$ ), 126.58 (benzodioxole $C_{5}$ ), 133.05 (benzodioxole $\mathrm{C}_{5}$ ), 141.25 (benzodioxole $\mathrm{C}_{7 \mathrm{a}}$ ), $144.92(\mathrm{~N}=\mathrm{C}), 146.55$ (benzodioxole $\mathrm{C}_{3 \mathrm{a}}$ ), 147.78 (benzodioxole $\mathrm{C}_{3 \mathrm{a}}$ ), 149.78 (benzodioxole $\mathrm{C}_{7 \mathrm{a}}$ ), $176.37(\mathrm{C}=\mathrm{S})$. MS (ESI) $(\mathrm{m} / \mathrm{z})$ : $[\mathrm{M}+\mathrm{H}]^{+} 423$. Anal. Calcd. for $\mathrm{C}_{16} \mathrm{H}_{12} \mathrm{BrN}_{3} \mathrm{O}_{4} \mathrm{~S}$ : C, 45.51; H, 2.86; N, 9.95. Found: C, 45.84; H, 2.79; N, 9.72.

\subsection{Biochemistry}

\subsubsection{Cell Culture and Drug Treatment}

C6 Rat glioma and NIH/3T3 mouse embryonic fibroblast cells were incubated in Dulbecco's Modified Eagle's Medium (DMEM) (Sigma, Deisenhofen, Germany) supplemented with 10\% fetal calf serum (Gibco, Paisley, UK). A549 Human lung adenocarcinoma cells were incubated in 90\% RPMI supplemented with 10\% fetal bovine serum (Gibco). All media were supplemented with $100 \mathrm{IU} / \mathrm{mL}$ penicillin-streptomycin (Gibco) and cells were incubated at $37^{\circ} \mathrm{C}$ in a humidified atmosphere of $95 \%$ air and $5 \% \mathrm{CO}_{2}$. Exponentially growing cells were plated at $2 \times 10^{4}$ cells $/ \mathrm{mL}$ into 96 -well microtiter tissue culture plates (Nunc, Roskilde, Denmark) and incubated for $24 \mathrm{~h}$ before the addition of the drugs (the optimum cell number for cytotoxicity assays was determined in preliminary experiments). The stock solutions of the compounds were prepared in dimethyl sulfoxide (DMSO; Sigma Aldrich, Poole, UK) and further dilutions were made with fresh culture medium (the concentration of DMSO in the final culture medium was $<0.1 \%$ which had no effect on the cell viability).

\subsubsection{MTT Assay}

The level of cellular 3-(4,5-dimethylthiazol-2-yl)-2,5-diphenyltetrazolium bromide (MTT) (Sigma) reduction was quantified as previously described in the literature with small modifications $[27,28]$. After $24 \mathrm{~h}$ of preincubation, the tested compounds and cisplatin (positive control) were added to give final concentration in the range 1.03-167 $\mu \mathrm{M}$ and the cells were incubated for $24 \mathrm{~h}$. At the end of this period, MTT was added to a final concentration of $0.5 \mathrm{mg} / \mathrm{mL}$ and the cells were incubated for $4 \mathrm{~h}$ at $37^{\circ} \mathrm{C}$. After the medium was removed, the formazan crystals formed by MTT metabolism were solubilized by addition of $200 \mu \mathrm{L}$ DMSO to each well and absorbance was read at $540 \mathrm{~nm}$ with a microtiter plate spectrophotometer (Bio-Tek Plate Reader, Winooski, VT, USA). Every concentration was repeated in three wells. $\mathrm{IC}_{50}$ values were defined as the drug concentrations that reduced absorbance to $50 \%$ of control values.

\subsubsection{Analysis of DNA Synthesis}

Analysis of DNA synthesis was measured by a Cell Proliferation ELISA, BrdU (colorimetric) kit (Roche, Mannheim, Germany). This immunostaining procedure is based on measuring the incorporation of bromodeoxyuridine (BrdU) into nuclear DNA in place of thymidine during the S-phase of the cell cycle using specific anti-BrdU antibodies [25]. Hence, such method provides 
a colorimetric measurement for DNA synthesis inhibition ratio of the carcinogenic cells. Firstly cells were seeded into 96 well flat-bottomed microtiter plates at a density of $2 \times 10^{3}$. The tumor cells were cultured in the presence of various doses of compounds 2, 3, 5, 9, 10 and cisplatin. Microtiter plates were incubated at $37^{\circ} \mathrm{C}$ in a $5 \% \mathrm{CO}_{2} / 95 \%$ air humidified atmosphere for $24 \mathrm{~h}$. Cells were labeled with $10 \mu \mathrm{L}$ BrdU solution for $2 \mathrm{~h}$ and then fixed. Anti-BrdU-POD $(100 \mu \mathrm{L})$ was added and incubated for 90 min. Finally, wells were washed with BPS and cells were incubated with substrate. Absorbance of the samples was measured with an ELX808-IU Bio-Tek apparatus at $492 \mathrm{~nm}$. All experiments were repeated two times. For each compound dose, dublicate wells were used.

\subsubsection{Flow Cytometric Analyses of Apoptosis}

After the cells were incubated with compounds 2, 5 and $\mathbf{1 0}$ at $\mathrm{IC}_{50}$ concentrations, phosphatidylserine externalization, which indicates early apoptosis, was measured by Annexin V-PI (BD Pharmingen, San Jose, CA, USA) on a BD FACSCalibur ${ }^{\mathrm{TM}}$ flow cytometer for $24 \mathrm{~h}$. Annexin V staining protocol was applied according to the manufacturer's instructions (BD Pharmingen). The cells were then briefly washed with cold phosphate buffer saline (PBS) and suspended in a binding buffer at a concentration of $1 \times 10^{6}$ cells $/ \mathrm{mL}$. Then, $100 \mu \mathrm{L}$ of this solution containing $1 \times 10^{5}$ cells was transferred to a $5 \mathrm{~mL}$ test tube. After $5 \mu \mathrm{L}$ of Annexin-V and PI was added, the cells were incubated for $15 \mathrm{~min}$ at room temperature in the dark. Then $400 \mu \mathrm{L}$ of $1 \mathrm{x}$ Binding Buffer was added to each tube and the cells were processed for data acquisition, and analyzed on a Becton-Dickinson FACS Aria using FACSDIVA Version 6.1.1. Software (BD Biosciences, San Jose, CA, USA).

\subsubsection{Analysis of Mitochondrial Membrane Potential (JC-1) by Flow Cytometry}

The cells were seeded in six-well plates at a density of $10^{5}$ cells $/ \mathrm{mL}$, and the $\mathrm{IC}_{50}$ dose of compounds 2, 5 and $\mathbf{1 0}$ was added to cells. The cells were incubated in $5 \% \mathrm{CO}_{2}$ air-conditioned atmosphere at $37{ }^{\circ} \mathrm{C}$. After $48 \mathrm{~h}$ of incubation, the cells were trypsinized, washed with PBS, and centrifuged at $400 \times g$ for $5 \mathrm{~min} .5,5^{\prime}, 6,6^{\prime}$-Tetrachloro-1,1',3,3'-tetraethylbenzimidazolylcarbocyanine iodide (JC-1) dye solution ( $1 \times$ assay buffer $+\mathrm{JC}-1$ stock solution) was added to the cells. The stock solution was prepared by dissolving DMSO. Then the samples were incubated at a temperature of $37^{\circ} \mathrm{C}$ for $10-15 \mathrm{~min}$. After incubation, the cells were washed twice with an assay buffer and analyzed by BD FACS Aria Cell Sorter Software version 6.1.1 flow cytometry (BD Biosciences). The cells showing mitochondrial membrane potential disruption were determined as a percentage of all cells.

\subsubsection{AChE and BuChE Inhibitory Activity}

AChE and BuChE inhibitory effects of the compounds were determined by Ellman's method with minor modifications (Electric eel acetylcholinesterase enzyme was used instead of bovine acetylcholinesterase enzyme and buffer was added $2.4 \mathrm{~mL}$ instead of $3 \mathrm{~mL}$ ) [29]. The compounds were dissolved in DMSO and tested at final concentration range 5-80 $\mu \mathrm{g} / \mathrm{mL}$. $20 \mu \mathrm{L}$ of enzyme (AChE or BuChE, $1 \mathrm{U} / \mathrm{mL}), 10 \mu \mathrm{L}$ sample added to $2.4 \mathrm{~mL}$ buffer, the mixture was incubated at $37^{\circ} \mathrm{C}$ for $15 \mathrm{~min}$. After $15 \mathrm{~min}$ incubation, $50 \mu \mathrm{L}$ of $0.01 \mathrm{M}$ 5,5'-dithiobis(2-nitrobenzoic acid) (DTNB) and $20 \mu \mathrm{L}$ of $75 \mathrm{mM}$ acetylthiocholine iodide (ATCI) or $25 \mathrm{mM}$ butyrylthiocholine iodide (BTCI) were added, and the final mixture was incubated at room temperature for $30 \mathrm{~min}$. Blank was prepared using $10 \mu \mathrm{L}$ of DMSO instead of the test sample, with all other procedures similar to those used in the case of the sample mixture. Absorbances were measured at $412 \mathrm{~nm}$ and $37^{\circ} \mathrm{C}$ using polystyrene cuvettes with spectrophotometer (UV-1700, Shimadzu). Experiment was done in triplicate. Galantamine was used as a positive control. Data are expressed as mean \pm standard deviation (SD). The inhibition (percent) of AChE or BuChE was calculated using the following equation:

$$
\mathrm{I}(\%)=100-\left(\mathrm{OD}_{\text {sample }} / \mathrm{OD}_{\text {control }}\right) \times 100
$$




\subsubsection{Sirtuin-1 Activity Detection by ELISA}

C6 glioma cells were administrated by $\mathrm{IC}_{50}$ or $\mathrm{IC}_{50} / 2$ concentrations of compound 5 and cisplatin for $24 \mathrm{~h}$. Cells were detached with trysin and then collected by centrifugation. After cells were washed by $1 \times$ PBS for three times, cell lysates were prepared by frozen cells at $\leq-20^{\circ} \mathrm{C}$. Freeze/thaw cycles were repeated for three times. Then cells were centrifuged at $1500 \times g$ for $10 \mathrm{~min}$ at $2-8{ }^{\circ} \mathrm{C}$ to remove cellular debris. Rat Sirtuin-1 activity protocol was applied according to the manufacturer's instructions (USCN, Life Science Inc., Wuhan, China). Briefly, all standards, reagents and samples were prepared. $100 \mu \mathrm{L}$ standard or sample were added to each well and incubated for $2 \mathrm{~h}$ at $37^{\circ} \mathrm{C}$. $100 \mu \mathrm{L}$ detection reagent $\mathrm{A}$ added and incubated $1 \mathrm{~h}$ at $37^{\circ} \mathrm{C}$. Then solutions were aspirated and wells were washed 3 times. Then $100 \mu \mathrm{L}$ detection reagent $\mathrm{B}$ was added and incubated for $30 \mathrm{~min}$ at $37^{\circ} \mathrm{C}$. Solutions were aspirated and washed 5 times. Then $90 \mu \mathrm{L}$ substrate solution added and incubated $15-25 \mathrm{~min}$ at $37^{\circ} \mathrm{C}$. After $50 \mu \mathrm{L}$ stop solution was added, plate was read at $450 \mathrm{~nm}$ with a microtiter plate spectrophotometer (Bio-Tek Plate Reader). Every concentration was repeated in double wells. The results were given as $\mathrm{ng} / \mathrm{mL}$.

\subsubsection{Statistical Analyses}

Statistical Package for the Social Sciences (SPSS, Chicago, IL, USA) for Windows 15.0 was used for statistical analysis. Data was expressed as Mean \pm SD. Comparisons were performed by one way ANOVA test for normally distributed continuous variables and post hoc analyses of group differences were expressed by the Tukey test. Also, Date were compared between two groups using Student's $t$-test. The $p<0.05$ was considered as statistically significant in this study.

\subsubsection{Docking Studies}

Compound 5 was docked to the active site of 4IG9. Ligand was set to the physiological $\mathrm{pH}$ $(\mathrm{pH}=7.4)$ at the protonation step and crystal structure of SIRT1 was retrieved from Protein Data Bank server, (PDB code: 4IG9). The structure of compound 5 was submitted in protein preparation module of Schrodinger's Maestro molecular modeling package. In molecular docking simulations: Glide/XP docking protocols were applied for the prediction of topologies of compound 5 at the active site of target structure. The formation of active site in the enzyme was determined from previous studies [12].

\section{Conclusions}

In the present paper, new benzodioxole-based thiosemicarbazone derivatives were synthesized and evaluated for their cytotoxicity against on A549 human lung adenocarcinoma, C6 rat glioma and NIH/3T3 mouse embryonic fibroblast cell lines. In order to examine the correlation between anticancer activity with cholinesterases, each derivative was investigated for its ability to inhibit AChE and BuChE. The most effective compounds were also investigated for their effects on DNA synthesis, apoptosis and mitochondrial membrane potential.

Among these compounds, compound $\mathbf{5}$ can be considered as the most promising anticancer agent against $\mathrm{C} 6\left(\mathrm{IC}_{50}=4.33 \pm 1.04 \mu \mathrm{M}\right)$ and $\mathrm{A} 549\left(\mathrm{IC}_{50}=10.67 \pm 1.53 \mu \mathrm{M}\right)$ cells and low toxicity to $\mathrm{NIH} / 3 \mathrm{~T} 3\left(\mathrm{IC}_{50}=21.33 \pm 5.77 \mu \mathrm{M}\right)$ cells. Compound 5 showed its anticancer activity against $\mathrm{C} 6$ cell line via the induction of apoptotic pathway, but this effect of compound 5 was independent of $\mathrm{ChE}$ inhibitory activity. The effects of compound 5 on SIRT1 activity were evaluated for underlying mechanism of apoptosis. The results indicated that compound 5 decreased SIRT1 levels in C6 rat glioma cells at $\mathrm{IC}_{50} / 2$ concentration, whereas compound 5 caused elevated SIRT1 levels compared to control at increased concentrations. This outcome pointed out that the effects of compound 5 on SIRT1 levels were dose dependent in C6 glioma cells. Docking studies were also carried out for compound 5 on SIRT1 to enlighten the exact position and interactions of this compound on the active site of enzyme. 
Supplementary Materials: The following are available online at http://www.mdpi.com/1420-3049/21/11/1598/s1.

Acknowledgments: This study was supported by Anadolu University Scientific Research Projects Commission under the grant no: 1407 S336 and 1605S318.

Author Contributions: M.D.A. and Z.A.K. designed the research; M.D.A. and B.S. performed the synthetic work and mainly wrote the manuscript; B.S. also carried out the docking studies. H.E.T and G.A.Ç. were responsible for the whole biochemistry part of the manuscript. M.D.A. was also responsible for the correspondence of the manuscript. All authors discussed, edited and approved the final version.

Conflicts of Interest: The authors declare no conflict of interest.

\section{References}

1. Silverstein, A.; Silverstein, V.; Silverstein Nunn, L. Cancer, Conquering a Deadly Disease; A Division of Lerner Publishing Group: Minneapolis, MN, USA, 2006; pp. 9-11.

2. Ruddon, R.W. Cancer Biology, 4th ed.; Oxford University Press: New York, NY, USA, 2007; pp. 4-5.

3. Almeida, C.A.; Barry, S.A. Cancer: Basic Science and Clinical Aspects; Wiley-Blackwell: Hoboken, NJ, USA, 2010; pp. 2-3.

4. Giamas, G.; Man, Y.L.; Hirner, H.; Bischof, J.; Kramer, K.; Khan, K.; Ahmed, S.S.; Stebbing, J.; Knippschild, U. Kinases as targets in the treatment of solid tumors. Cell Signal 2010, 22, 984-1002. [CrossRef] [PubMed]

5. Von Mehren, M.; Widmer, N. Correlations between imatinib pharmacokinetics, pharmacodynamics, adherence, and clinical response in advanced metastatic gastrointestinal stromal tumor (GIST): An emerging role for drug blood level testing? Cancer Treat. Rev. 2011, 37, 291-299. [CrossRef] [PubMed]

6. Sestak, V.; Stariat, J.; Cermanova, J.; Potuckova, E.; Chladek, J.; Roh, J.; Bures, J.; Jansova, H.; Prusa, P.; Sterba, M.; et al. Novel and potent anti-tumor and anti-metastatic di-2-pyridylketone thiosemicarbazones demonstrate marked differences in pharmacology between the first and second generation lead agents. Oncotarget 2015, 6, 42411-42428. [PubMed]

7. Massoulié, J.; Perrier, N.; Noureddine, H.; Liang, D.; Bon, S. Old and new questions about cholinesterases. Chem. Biol. Interact. 2008, 175, 30-44. [CrossRef] [PubMed]

8. Pérez-Aguilar, B.; Vidal, C.J.; Palomec, G.; García-Dolores, F.; Gutiérrez-Ruiz, M.C.; Bucio, L.; Gómez-Olivares, J.L.; Gómez-Quiroz, L.E. Acetylcholinesterase is associated with a decrease in cell proliferation of hepatocellular carcinoma cells. Biochim. Biophys. Acta 2015, 1852, 1380-1387. [CrossRef] [PubMed]

9. Xi, H.-J.; Wu, R.-P.; Liu, J.-J.; Zhang, L.-J.; Li, Z.-S. Role of acetylcholinesterase in lung cancer. Thorac. Cancer 2015, 6, 390-398. [CrossRef] [PubMed]

10. Firestein, R.; Blander, G.; Michan, S.; Oberdoerffer, P.; Ogino, S.; Campbell, J.; Bhimavarapu, A.; Luikenhuis, S.; de Cabo, R.; Fuchs, C.; et al. The SIRT1 deacetylase suppresses intestinal tumorigenesis and colon cancer growth. PLoS ONE 2008, 3, 2020-2029. [CrossRef] [PubMed]

11. Finkel, T.; Deng, C.X.; Mostoslavsky, R. Recent progress in the biology and physiology of sirtuins. Nature 2009, 460, 587-591. [CrossRef] [PubMed]

12. Davenport, A.M.; Huber, F.M.; Hoelz, A. Structural and functional analysis of human SIRT1. J. Mol. Biol. 2014, 426, 526-541. [CrossRef] [PubMed]

13. Feng, H.; Guo, P.; Wang, J.; Xu, J.; Xie, C.; Gao, F. Expression of Leptin and Sirtuin-1 is associated with poor prognosis in patients with osteosarcoma. Pathol. Res. Pract. 2016, 4, 319-324. [CrossRef] [PubMed]

14. Lin, Z.; Fang, D. The Roles of SIRT1 in Cancer. Genes Cancer 2013, 4, 97-104. [CrossRef] [PubMed]

15. Kalinowski, D.S.; Quach, P.; Richardson, D.R. Thiosemicarbazones: The new wave in cancer treatment. Future Med. Chem. 2009, 1, 1143-1151. [CrossRef] [PubMed]

16. Chapman, T.R.; Kinsella, T.J. Ribonucleotide reductase inhibitors: A new look at an old target for radiosensitization. Front. Oncol. 2012, 1. [CrossRef] [PubMed]

17. Moorthy, N.S.; Cerqueira, N.M.; Ramos, M.J.; Fernandes, P.A. Aryl- and heteroaryl-thiosemicarbazone derivatives and their metal complexes: A pharmacological template. Recent Pat. Anticancer Drug Discov. 2013, 8, 168-182. [CrossRef] [PubMed]

18. Yu, Y.; Kalinowski, D.S.; Kovacevic, Z.; Siafakas, A.R.; Jansson, P.J.; Stefani, C.; Lovejoy, D.B.; Sharpe, P.C.; Bernhardt, P.V.; Richardson, D.R. Thiosemicarbazones from the old to new: İron chelators that are more than just ribonucleotide reductase inhibitors. J. Med. Chem. 2009, 52, 5271-5294. [CrossRef] [PubMed] 
19. Stefani, C.; Al-Eisawi, Z.; Jansson, P.J.; Kalinowski, D.S.; Richardson, D.R. Identification of differential anti-neoplastic activity of copper bis(thiosemicarbazones) that is mediated by intracellular reactive oxygen species generation and lysosomal membrane permeabilization. J. Inorg. Biochem. 2015, 152, 20-37. [CrossRef] [PubMed]

20. Jagadeesh, M.; Rashmi, H.K.; Subba Rao, Y.; Sreenath Reddy, A.; Prathima, B.; Uma Maheswari Devi, P.; Reddy, A.V. Synthesis and spectroscopic characterization of 3,4-difluoroacetophenone-thiosemicarbazone and its palladium(II) complex: Evaluation of antimicrobial and antitumour activity. Spectrochim. Acta A Mol. Biomol. Spectrosc. 2013, 115, 583-587. [CrossRef] [PubMed]

21. Taşdemir, D.; Karaküçük-İyidoğan, A.; Ulaşli, M.; Taşkin-Tok, T.; Oruç-Emre, E.E.; Bayram, H. Synthesis, molecular modeling, and biological evaluation of novel chiral thiosemicarbazone derivatives as potent anticancer agents. Chirality 2015, 27, 177-188. [CrossRef] [PubMed]

22. Bacher, F.; Dömötör, O.; Chugunova, A.; Nagy, N.V.; Filipović, L.; Radulović, S.; Enyedy, É.A.; Arion, V.B. Strong effect of copper(II) coordination on antiproliferative activity of thiosemicarbazone-piperazine and thiosemicarbazone-morpholine hybrids. Dalton Trans. 2015, 44, 9071-9090. [CrossRef] [PubMed]

23. Lin, Z.P.; Ratner, E.S.; Whicker, M.E.; Lee, Y.; Sartorelli, A.C. Triapine disrupts CtIP-mediated homologous recombination repair and sensitizes ovarian cancer cells to PARP and topoisomerase inhibitors. Mol. Cancer Res. 2014, 12, 381-393. [CrossRef] [PubMed]

24. Wang, H.H.; Qiu, K.M.; Cui, H.E.; Yang, Y.S.; Yin-Luo; Xing, M.; Qiu, X.Y.; Bai, L.F.; Zhu, H.L. Synthesis, molecular docking and evaluation of thiazolyl-pyrazoline derivatives containing benzodioxole as potential anticancer agents. Bioorg. Med. Chem. 2013, 21, 448-455. [CrossRef] [PubMed]

25. Malikova, J.; Swaczynova, J.; Kolar, Z.; Strnad, M. Anticancer and antiproliferative activity of natural brassinosteroids. Phytochemistry 2008, 69, 418-426. [CrossRef] [PubMed]

26. Green, D.R.; Reed, J.C. Mitochondria and apoptosis. Science 1998, 281, 1309-1312. [CrossRef] [PubMed]

27. Mosmann, T. Rapid colorimetric assay for cellular growth and survival: Application to proliferation and cytotoxicity assays. J. Immunol. Methods 1983, 16, 55-63. [CrossRef]

28. Keiser, K.; Johnson, C.C.; Tipton, D.A. Cytotoxicity of mineral trioxide aggregate using human periodontal ligament fibroblasts. J. Endod. 2000, 26, 288-291. [CrossRef] [PubMed]

29. Ellman, G.L.; Courtney, K.D.; Anders, V.; Featherstone, R.M. A new and rapid colorimetric determination of acetylcholinesterase activity. Biochem. Pharmacol. 1961, 7, 88-95. [CrossRef]

Sample Availability: Samples of the compounds (1-10) are available from the authors.

(C) 2016 by the authors; licensee MDPI, Basel, Switzerland. This article is an open access article distributed under the terms and conditions of the Creative Commons Attribution (CC-BY) license (http://creativecommons.org/licenses/by/4.0/). 